\title{
ГЕОХИМИЧЕСКИЕ СОБЫТИЯ НА ГРАНИЦЕ СЕНОМАНА И ТУРОНА: СВЯЗЬ АНОКСИИ С ВУЛКАНИЗМОМ, КЛИМАТОМ И ОКЕАНСКОЙ ЦИРКУЛЯЦИЕЙ

\author{
О.Л. Савельева
}

\author{
Институт вулканологии и сейсмологии ДВО РАН, \\ 683006 Петропавловск-Камчатский, бульвар Пийпа, 9, Россия
}

\begin{abstract}
Проведен детальный анализ хемостратиграфических исследований уровня OAE2 (океанского аноксического события Бонарелли на границе сеномана и турона) в разных регионах мира. Рассмотрены окислительно-восстановительные условия в различных бассейнах в течение этого события. Палеоокеанические отложения Восточной Камчатки, содержащие следы OAЕ2, сопоставлены с аналогичными отложениями на подводных вулканических возвышенностях северо-западной части Тихого океана. Приведены данные об аномалиях металлов и экскурсах изотопно-углеродных кривых в пограничных отложениях сеномана и турона. Радиоизотопные датировки вулканических пород некоторых крупных магматических провинций сопоставлены со временем проявления ОАЕ2. Проанализированы причины и закономерности события Бонарелли, взаимодействие определяющих его факторов. Ведущую роль в развитии OAE2 сыграло поступление в океаны питательных веществ в результате повышенной магматической и гидротермальной активности и континентального выветривания. Распределение в пространстве областей накопления черных сланцев контролировалось особенностями океанской циркуляции. Геохимические и биохимические процессы, связанные с повышенной продуктивностью, вели к снижению последней и возвращению океана к кислородным условиям.
\end{abstract}

OAE2, углеродистые породы, граница сеномана и турона, биопродуктивность, крупная магматическая провиниия, редокс, стабильные изотопы, океанская ичиркуляичия.

\section{GEOCHEMICAL EVENTS AT THE CENOMANIAN-TURONIAN BOUNDARY: RELATION OF ANOXIA WITH VOLCANISM, CLIMATE, AND OCEAN CIRCULATION}

\section{O.L. Savelyeva}

The paper presents a detailed review of chemostratigraphic data on the Bonarelli oceanic anoxic event (OAE2) at the Cenomanian-Turonian boundary from different regions worldwide, with a focus on the respective redox conditions in the basins, metal anomalies, and $\delta^{13} \mathrm{C}$ excursions. Marine sediments with OAE2 signatures in Eastern Kamchatka are compared with their counterparts from submarine volcanic rises in the northwestern Pacific. The available isotopic ages of lavas from some large igneous provinces are correlated with the age of OAE2. The Bonarelli event was triggered and governed by several interrelated factors: volcanism, climate, and ocean circulation. The supply of nutrients into oceans as a result of enhanced magmatism, hydrothermal activity, and weathering on continents played an important role in maintaining anoxia. The spatial patterns of black-shale deposition were controlled by ocean circulation. Geochemical and biochemical processes associated with high productivity ultimately led to its reduction and to the recovery of oxic conditions in oceans.

OAE2, carbonaceous rocks, Cenomanian-Turonian boundary, bioproductivity, large igneous province, redox, stable isotopes, ocean circulation

\section{ВВЕДЕНИЕ}

На современном этапе развития стратиграфии большое внимание уделяется критическим рубежам, к которым приурочены масштабные перестройки климата и химии океана, а также разнообразные биотические события. Методы событийной стратиграфии в комплексе с палеонтологическими данными позволяют скоррелировать отложения, накапливавшиеся в пределах разных океанов. Примерами таких глобальных реперов являются эпизоды распространения обстановок дефицита или отсутствия кислорода в морских и океанских бассейнах - океанские аноксические события (OAE - Oceanic Anoxic Events) [Schlanger, Jenkyns, 1976]. Наибольшим количеством ОАЕ характеризуется меловой период; первоначально они выделялись по горизонтам углеродистых пород, накапливавшихся в разнообразных обстановках: от глубоких океанов до шельфовых морей. Для каждого ОАЕ характерны индивидуальные черты, проявляющиеся в их связи с вулканическими, климатическими и биотическими событиями и отражающиеся в литологии и геохимии разрезов [Orth et al., 1993; Jenkyns, 2010]. В связи с этим уровни

() О.Л. Савельева ${ }^{\square}, 2019$

凶e-mail: savelyeva@kscnet.ru 
OAE рассматриваются не только как важные реперы в событийной стратиграфии, но и как ключевые объекты для изучения палеоклимата и нарушений равновесия в системе океан-климат.

Среди аноксических событий середины мела граничное сеноман-туронское (C/T) событие (OAE2) характеризуется наибольшими скоростями захоронения органического углерода $\left(\mathrm{C}_{\text {орг }}\right)$. Это событие носит также название Бонарелли - в честь Гвидо Бонарелли (1871-1951 гг.), впервые описавшего черные сланцы в верхах сеномана в разрезах Боттачионе и Контесса возле г. Губбио в Центральных Апеннинах. Надо отметить, что «уровень Бонарелли» рассматривается обычно как региональный стратиграфический маркер, распространенный в бассейне Умбрия-Марке Центральной Италии [Luciani, Cobianchi, 1999; Mort et al., 2007b], но под «событием Бонарелли» подразумевают резкое увеличение накопления углеродистых пород в глобальном масштабе [Jenkyns et al., 2007]. Захоронение в осадках огромного количества легкого $\mathrm{C}_{\text {орг }}$ вызвало временный сдвиг изотопного состава углерода атмосферы и морской воды к более тяжелым значениям (т. е. повышение $\delta^{13}$ C) [Kuypers et al., 2002; Tsikos et al., 2004; Jenkyns, 2010]. Отлагающиеся карбонаты и органическое вещество (ОВ) восприняли этот изотопно-углеродный сигнал и зафиксировали его в осадочных породах. Идентификация и корреляция OAE2 основаны на данных изотопии углерода, объединенных с биостратиграфией и, где это возможно, с радиоизотопным датированием [Jenkyns et al., 2007]. При этом содержания $\mathrm{C}_{\text {орг }}$ в конкретных разрезах могут быть очень различными.

В данной статье сделан обзор современных достижений хемостратиграфических исследований уровня OAE2. Рассмотрены причины и закономерности развития этого события, взаимодействие определяющих его факторов (вулканизма, климата, океанской циркуляции и т.д.). Приведены модели океанской циркуляции разных авторов и возможные причины изменений климата в конце сеномана и начале турона.

\section{ГЕОГРАФИЧЕСКОЕ РАСПРОСТРАНЕНИЕ РАЗРЕЗОВ, СОДЕРЖАЩИХ СЛЕДЫ ОАЕ2}

Ранний, но обширный обзор данных об отложениях, содержащих следы события Бонарелли, представлен в работе C.О. Шлангера с соавторами [Schlanger et al., 1987]. В ней рассмотрены разрезы Европы, Атлантики, Западного Внутреннего бассейна США, Аляски, Канадского Арктического архипелага, Центральной и Южной Америки, Северной и Центральной Африки, Тихого и Индийского океанов, приведены сведения по литологии и изотопии углерода. За последние три десятилетия многие из этих разрезов были детально изучены, а также открыты и исследованы новые (рис. 1). В качестве примеров можно привести скв. 1260B ODP на возвышенности Демерара [Hetzel et al., 2009], скв. 1138 ODP на плато Кергелен [Holbourn, Kuhnt, 2002], скв. S57 и другие в бассейне Тарфайя (Марокко) [Kolonic et al., 2005], разрезы Египта [El-Sabbagh et al., 2011], Тибета [Wan et al., 2003; Li et al., 2009; Bomou et al., 2013], Сицилии [Scopelliti et al., 2004], Греции [Karakitsios et al., 2007], Кавказа [Левитан и др., 2010; Гаврилов и др., 2013], севера Сибири [Лебедева, Зверев, 2003], о. Аксель-Хейберг [Lenniger et al., 2014; Herrle et al., 2015], ряд разрезов складчатого обрамления Тихого океана [Takashima et al., 2004; Савельев и др., 2007; Hasegawa et al., 2013; Du Vivier et al., 2015b].

Стратотипом C/Т границы избран разрез вблизи Пуэбло (Колорадо, США), дающий точку отсчета для датирования разрезов ОАЕ2 на основе высокоразрешающей биостратиграфии, изотопно-углеродной кривой и абсолютного датирования бентонитовых прослоев. Наиболее изученными остаются разрезы Западной Европы, Западного Внутреннего бассейна США, Северной Африки, Северной Атлантики. В следующей главе дана краткая характеристика условий редокса в океанах позднего сеномана, восстановленных различными методами в этих разрезах.

\section{РАСПРОСТРАНЕНИЕ УГЛЕРОДИСТЫХ ОСАДКОВ И УСЛОВИЯ РЕДОКСА ВО ВРЕМЯ ОАЕ2}

В данной статье мы будем пользоваться следующей градацией окислительно-восстановительных условий (редокса) в придонных водах [Tyson, Pearson, 1991]: кислородные (более $2 \mathrm{mл}_{2} /$ л $\mathrm{H}_{2} \mathrm{O}$ ), дизоксидные $\left(0.2-2.0\right.$ мл $\left.\mathrm{O}_{2} / л \mathrm{H}_{2} \mathrm{O}\right)$, субоксидные $\left(0-0.2 \mathrm{mл}_{2} /\right.$ л $\left.\mathrm{H}_{2} \mathrm{O}\right)$, аноксидные $\left(0\right.$ мл $\mathrm{O}_{2} /$ л $\left.\mathrm{H}_{2} \mathrm{O}\right)$. В этих условиях $\mathrm{H}_{2} \mathrm{~S}$ может присутствовать в осадках на различной глубине. Эвксинными будем называть условия отсутствия $\mathrm{O}_{2}$ при доминирующем присутствии $\mathrm{H}_{2} \mathrm{~S}$ в осадках и водной толще [Tribovillard et al., 2006].

Обстановки палеоредокса наиболее надежно устанавливаются по комплексам биоты, изменениям концентрации некоторых биомаркеров, редокс-чувствительных металлов, а также по возмущениям редокс-чувствительных изотопных систем [Pogge von Strandmann et al., 2013]. Желательно применение комплекса показателей, особенно при использовании таких характеристик, как отношения S/C, C/P, степень пиритизации, содержание реакционноспособного Fe, размер зерен пирита [Meyer, Kump, 2008].

Распределение в разрезах изотопов некоторых элементов дает возможность оценить глобальное распространение аноксидных и эвксинных условий во время события Бонарелли. Эти оценки отличаются у разных исследователей. Посредством моделирования изотопных кривых серы и углерода было 


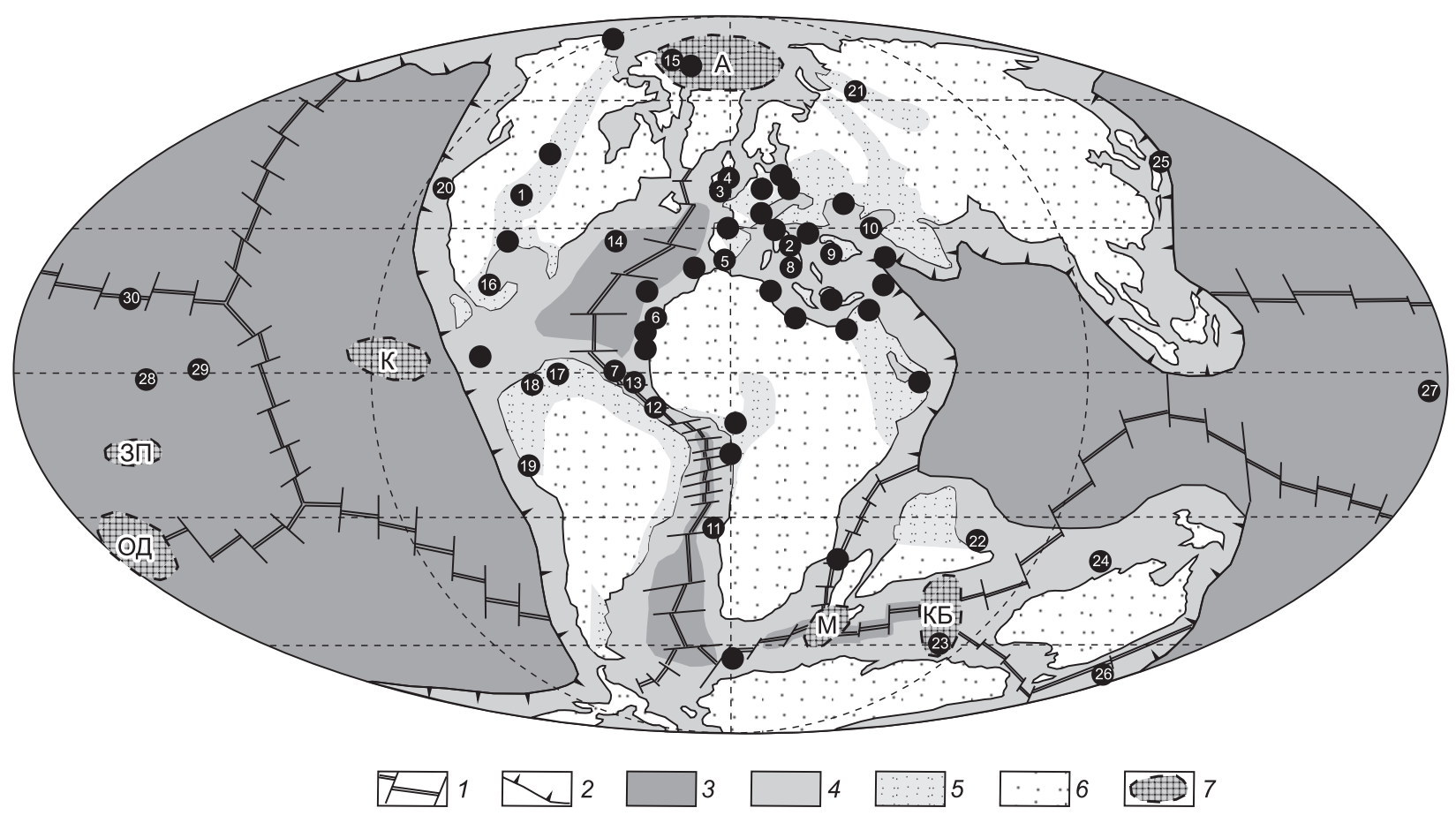

Рис. 1. Палеогеографическая карта середины мелового периода (90 млн л. н.).

1 - срединно-океанические хребты и трансформные разломы, 2 - зоны субдукции, 3 - глубокий океан, 4 - мелководный океан, 5 - эпиконтинентальные моря, 6 - суша, 7 - крупные магматические провинции (К - Карибское плато, ОД - плато Онтонг-Джава, ЗП - подводные горы Западной Пацифики, А - Арктическая провинция, КБ - плато Кергелен и хр. Брокен, М - Мадагаскарская провинция). Кружками обозначены места формирования разрезов, содержащих интервал ОАЕ2, установленный по повышенным содержаниям $\mathrm{C}_{\text {орг }}$ и/или изотопно-углеродному экскурсу. Цифрами обозначено современное положение разрезов, упомянутых в тексте статьи: 1 - Пуэбло, 2 - Центральные Апеннины (разрезы Фурло, Боттачионе, Контесса, Чебрара), 3 - Истборн, 4 - Саут-Ферриби, 5 - Манильва (Южная Испания), 6 - Тарфайя (Марокко), 7 - возвышенность Демерара, 8 - о. Сицилия, 9 - Греция, 10 - Кавказ, 11 - скв. 530 DSDP, 12 - скв. 367 DSDP, 13 - скв. 144 DSDP, 14 - скв. 603 DSDP, 15 - о. Аксель-Хейберг, 16 - Мексика, 17 - Маракайбо (Венесуэла), 18 - Колумбия, 19 - Перу, 20 - Калифорния (формация Баден Каньон), 21 - север Сибири, 22 - Тибет, 23 - плато Кергелен, 24 - плато Эксмут, 25 - о. Хоккайдо (группа Эзо), 26 Новая Зеландия, 27 - скв. 585 DSDP (Восточно-Марианский бассейн), 28 - скв. 305 DSDP (возвышенность Шатского), 29 скв. 310 DSDP (возвышенность Хесса), 30 - п-ов Камчатский Мыс (Восточная Камчатка). Положение континентов, по данным [Scotese, 2004], использованы данные [Schlanger et al., 1987; Tarduno et al., 1998; Takashima et al., 2006; Trabucho-Alexandre et al., 2010; Lenniger et al., 2014].

установлено, что максимальная площадь распространения эвксинных придонных вод во время ОАЕ2 составляла $2.5-7.0 \%$ морского дна (в 15-40 раз больше, чем в настоящее время) [Owens et al., 2013]. Моделирование по изотопии урана показало, что во время ОАЕ2 распространенность аноксидных, в том числе эвксинных, обстановок могла составлять до $\sim 1-2 \%$ - в три раза больше, чем ныне [MontoyaPino et al., 2010]. В любом случае это означает, что значительная часть Мирового океана в течение события Бонарелли оставалась субоксидной и/или кислородной. Отложение ОВ началось на юго-западе Северной прото-Атлантики (СПА) еще до изотопно-углеродного экскурса и затем распространилось на север СПА, в океан Тетис [Kuroda, Ohkouchi, 2006] и в Западный Внутренний бассейн [Mort et al., 2007a], где оно началось уже после начала изотопно-углеродного экскурса.

Изучение интервалов разрезов, соответствующих ОАЕ2, показывает, что эвксинные обстановки были распространены главным образом в прото-Атлантике, где происходило и наибольшее накопление $\mathrm{C}_{\text {орг }}$ [Meyer, Kump, 2008]. На возвышенности Демерара, в бассейнах Тарфайя и Маракайбо тонкослоистые богатые органикой осадки накапливались с позднего апта по ранний турон, с максимальным захоронением $\mathrm{C}_{\text {орг }}$ в течение OAE2 [Jenkyns et al., 2007; Martin et al., 2012]. Во многих атлантических скважинах имеются свидетельства существования эвксинных условий в фотической зоне непосредственно перед и во время OAE2 [Sinninghe Damsté, Köster, 1998; Kuypers et al., 2002; Kolonic et al., 2005; Forster et al., 2008; Jenkyns, 2010]. В то же время эвксинные условия были более распространены на юге СПА (где на разных глубинах накапливалось большое количество морского ОВ), чем на севере (где преобладало наземное ОВ, и лишь отдельные прослои содержали морское ОВ) [Trabucho-Alexandre et al., 
2010; Owens et al., 2012]. В некоторых районах на севере СПА, в западной части океана Тетис и в Западном Внутреннем бассейне Северной Америки преобладали кислородные обстановки [Westermann et al., 2010; Owens et al., 2012; Eldrett et al., 2014], осадконакопление происходило здесь выше зоны кислородного минимума [Schlanger et al., 1987].

Во многих разрезах, сформировавшихся в Северной и Южной Атлантике, Мексиканском море, Западном Внутреннем бассейне, Западном Тетисе и Перитетисе, имеются свидетельства изменчивости условий редокса в течение OAE2 [Найдин, 1993; Forster et al., 2008; Гаврилов и др., 2013; Núñez-Useche et al., 2016], а также чередующегося преобладания процессов нитратредукции и сульфатредукции в водной толще [Jenkyns et al., 2007]. Смена окислительно-восстановительных условий нередко коррелируется с колебаниями орбитальных параметров Земли [Sageman et al., 1997; Kuypers et al., 2004a; Mort et al., 2008], которые оказывали влияние на расположение и силу пассатов и вызывали флюктуации апвеллинга богатых питательными веществами промежуточных вод [Kolonic et al., 2005; Dickson et al., 2016].

Проявления события Бонарелли в прото-Индийском океане и восточной части океана Тетис представлены и изучены гораздо хуже. На плато Кергелен (Индийский океан) имеются признаки кратковременной дизоксии во время OAE2 [Holbourn, Kuhnt, 2002]. Материал из различных разрезов Тибета (Восточный Тетис) указывает на преобладающие кислородные и дизоксидные обстановки [Wan et al., 2003; Li et al., 2009; Bomou et al., 2013]. Данные с северо-западной подводной окраины Австралии свидетельствуют об отложении черных сланцев на шельфе, в пределах зоны кислородного минимума (скв. 762 и 763 DSDP на плато Эксмут), и одновременное формирование осадков в кислородных условиях на большей глубине [Thurow et al., 1992].

В ряде районов Тихого океана на уровне OAE2 не было обнаружено осадков со следами аноксии и высоким содержанием $\mathrm{C}_{\text {орг }}$. Например, они отсутствуют в разрезах Перу, сформировавшихся в задуговом бассейне [Navarro-Ramirez et al., 2016], а также в известняках францисканского комплекса Калифорнии, отложившихся на симаунтах Восточной Пацифики на $17^{\circ}$ ю.ш. [Sliter, Premoli Silva, 1990]. В Новой Зеландии на уровне OAE2 наблюдаются красные слои, а состав микро- и макрофоссилий меняется раньше, чем в разрезах Европы, и до изотопно-углеродного экскурса [Hasegawa et al., 2013]. В разрезах преддуговых прогибов (группа Эзо о. Хоккайдо, формация Баден Каньон Калифорнии) небольшие содержания $\mathrm{C}_{\text {орг }}$ наземного происхождения наблюдаются по всему разрезу, однако истощение кислорода здесь дискуссионно. Появлялись сообщения о кислородных условиях во время OAE2 в этих районах [Nemoto, Hasegawa, 2011; Takashima et al., 2011], однако впоследствии начало OAE2 в группе Эзо было перенесено на 22.5 м вверх по разрезу, на уровень, где степень пиритизации возрастает [Du Vivier et al., 2015b], a также в формации Баден Каньон были отмечены высокие содержания $\mathrm{C}_{\text {орг }}$ на интервале изотопно-углеродного экскурса, соответствующего OAE2 [Magtoto et al., 2014], так что, возможно, некоторое истощение кислорода здесь имело место. В скважине 463 DSDP OAE2 проявлено только экскурсами ${ }^{87} \mathrm{Sr} /{ }^{86} \mathrm{Sr}$ и $\delta^{13} \mathrm{C}$ [Ando et al., 2009], в скважине 869 ODP - экскурсом $\delta^{13} \mathrm{C}$ [Jenkyns et al., 1995].

Отложения с повышенным содержанием $\mathrm{C}_{\text {орг }}(9.3-9.9 \%$ ) на уровне ОАЕ2 совпадают с изотопноуглеродным экскурсом только в экваториальной части Тихого океана [Owens et al., 2013]. Они присутствуют в Восточно-Марианском бассейне (скв. 585 DSDP), куда были переотложены мутьевыми потоками, а также в первичном залегании в виде тонких слоев среди карбонатных и кремнистых осадков на возвышенностях Шатского и Хесса (скв. 305 и 310 DSDP соответственно) [Schlanger et al., 1987]. В аналогичной обстановке на поверхности симаунта отложился тонкий прослой с высоким содержанием $\mathrm{C}_{\text {орг }}$ (до 53 \%), залегающий среди карбонатно-кремнистых отложений на п-ове Камчатский Мыс (Восточная Камчатка) [Savelyeva et al., 2010]. Состав радиоляриевой фауны во вмещающих углеродистый прослой породах позволяет предположить их формирование на палеоширотах $20-30^{\circ}$ с.ш. [Вишневская, 2001]. По соотношениям редокс-чувствительных элементов установлены эвксинные условия в придонных водах [Savelyeva et al., 2010]. Необходимо отметить, что в Тетисе и Атлантике красные слои обычно появляются в разрезах выше уровня ОАЕ2 и только изредка встречаются в отложениях, разделяющих уровни аноксических событий, тогда как в пелагических разрезах Тихого океана углеродистые прослои могут быть заключены в красноцветных отложениях, представленных красно-коричневыми кремнями и оранжевым писчим мелом в скв. 305 и красно-коричневыми яшмами и розовыми известняками на п-ове Камчатский Мыс. Эти данные свидетельствуют о господстве на тихоокеанских палеоглубинах кислородных условий, лишь на короткое время и на ограниченном пространстве сменявшихся аноксидными и эвксинными. Приуроченность углеродистых прослоев к подводным возвышенностям Пацифики обычно связывают с совпадением их вершин с локальными зонами кислородного минимума, в пределах которых осадки обогащались $\mathrm{C}_{\text {орг }}$ [Dean et al., 1981].

Итак, событие Бонарелли задокументировано во множестве скважин и обнажений в бассейнах всех океанов на разных глубинах, широтах и в разных условиях осадконакопления. Далеко не везде оно сопровождается обогащением осадка $\mathrm{C}_{\text {орг }}$. Углеродистые осадки распределены крайне неравномерно, и их отложение не вполне синхронно. Неоднородные условия редокса в течение OAE2 создаются регио- 
нальными и локальными различиями биопродуктивности, зависящими от глубины и конфигурации бассейна, океанской циркуляции и поступления в океаны питательных веществ. Изученность этих факторов и обоснование механизмов геохимическими методами характеризуется в последующих разделах статьи.

\section{АНОМАЛИИ ПРИМЕСНЫХ ЭЛЕМЕНТОВ НА УРОВНЕ ОАЕ2}

Аноксидные условия обычно вызывают обогащение осадка редокс-чувствительными элементами. Например, большие количества $\mathrm{As}, \mathrm{Sb}, \mathrm{Co}, \mathrm{Cr}, \mathrm{Cu}, \mathrm{Mo}, \mathrm{Ni}, \mathrm{Pb}, \mathrm{Zn}, \mathrm{Cd}, \mathrm{Re}, \mathrm{U}$ и V могут быть зафиксированы в осадках в восстановительных условиях путем осаждения в виде сульфидов, соосаждения с сульфидами железа, поглощения ОВ, биоконцентрации или же путем осаждения в виде металлоорганических комплексов в раннем диагенезе [Tribovillard et al., 2006; Turgeon, Brumsack, 2006; Núñez-Useche et al., 2016]. В то же время многие исследователи считают, что аномалии металлов, обнаруженные в осадках, связанных с OAE, не могут быть объяснены без привлечения повышенной поставки некоторых элементов в морскую воду [Trabucho-Alexandre et al., 2010; Núñez-Useche et al., 2016]. Дополнительный источник металлов легче выявить в тех случаях, когда аномалии их содержаний в разрезах не коррелируют со степенью аноксии. Именно такой случай наблюдается в 16 разрезах Западного Внутреннего бассейна США, где в верхах сеномана были выявлены 1 или 2 близкорасположенных пика содержаний $\mathrm{Sc}, \mathrm{Ti}, \mathrm{V}, \mathrm{Cr}, \mathrm{Mn}, \mathrm{Co}, \mathrm{Ni}, \mathrm{Ir}, \mathrm{Pt}$ и $\mathrm{Au}$ [Orth et al., 1993]. В частности для Ir максимальные содержания составляют 0.11 мг/т при местном фоне 0.017 мг/т. Последующее изучение аномалий металлов в разрезе Рок Каньон (Пуэбло) показало, что для верхней аномалии типично обогащение $\mathrm{Mn}, \mathrm{Ba}, \mathrm{Y}, \mathrm{Au}$ и $\mathrm{Sr}$ примерно в 8-20 раз выше фона и обогащение $\mathrm{Sc}, \mathrm{As}, \mathrm{Bi}, \mathrm{Ag}, \mathrm{Na}, \mathrm{Cr}, \mathrm{Co}, \mathrm{Ni}, \mathrm{Cu}, \mathrm{Cd}, \mathrm{Fe}, \mathrm{V}, \mathrm{Se}, \mathrm{W}, \mathrm{Pb}, \mathrm{Mg}$ и Тi в 3-6 раз выше фона. Нижняя аномалия характеризуется обогащением $\mathrm{Mn}, \mathrm{Na}, \mathrm{Ba}, \mathrm{Cr}, \mathrm{Co}$ и $\mathrm{Sc}$ примерно в 5-7 раз выше фона, а также $\mathrm{Sr}, \mathrm{Y}, \mathrm{Cu}, \mathrm{Ag}, \mathrm{W}, \mathrm{Ni}, \mathrm{Bi}, \mathrm{Fe}, \mathrm{Se}, \mathrm{V}, \mathrm{Au}, \mathrm{As}, \mathrm{Pb}, \mathrm{Mg}, \mathrm{Ti}$ и Cd в 2-4 раза выше фона [Snow et al., 2005]. Наиболее ярко выражены аномалии Со (рис. 2). Отсутствие микросферул или шоковых минеральных зерен, обогащение на уровне иридиевой аномалии $\mathrm{Sc}, \mathrm{Ti}, \mathrm{V}$ и $\mathrm{Mn}$, которые обычно не ассоциируют с метеоритами, свидетельствуют против импактного источника аномалий. Резкий характер аномалий и удаленность от источников терригенного сноса не позволяет связывать аномалии с изменением режима континентального выветривания. Соотношения элементов на аномальных уровнях близки к отношениям в гавайских лавах и базальтах $\mathrm{COX}$, что указывает, скорее, на вулканогенный/гидротермальный источник металлов [Orth et al., 1993]. Нижний более слабый интервал аномалий металлов коррелирует с началом позитивного экскурса $\delta^{13} \mathrm{C}_{\text {орг }}$ в начале OAE2 в Рок Ка-

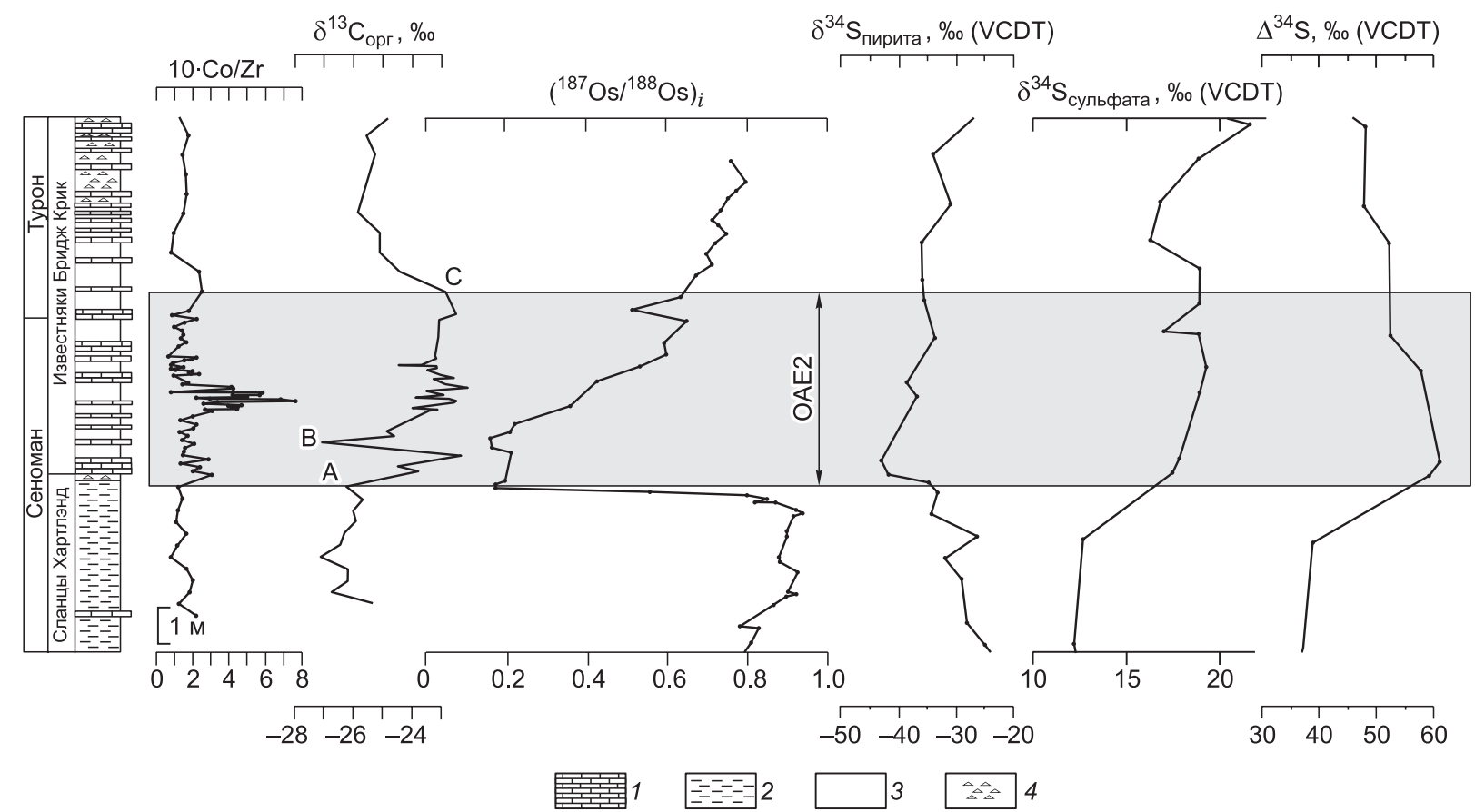

Рис. 2. Обобщение геохимических данных по разрезам сеноман-туронского граничного интервала в районе Пуэбло (Колорадо).

Литология, по [Sageman et al., 2006] с упрощением: 1 - известняки, 2 - известковые сланцы, 3 - мергели и известковые сланцы, 4 - линзы обломочных известняков. Кривые $\mathrm{Co} / \mathrm{Zr}$ и $\delta^{13} \mathrm{C}_{\text {орг }}$, по [Snow et al., 2005], ${ }^{187} \mathrm{Os} /{ }^{188} \mathrm{Os}$, по [Du Vivier et al., 2015b], изотопные кривые серы, по [Adams et al., 2010]. A, B, C — стратиграфические уровни. 
ньон, в 4 м ниже С/Т границы. Верхний, более сильный интервал аномалий расположен в начале плато значений кривой $\delta^{13} \mathrm{C}_{\text {орг }}$ (см. следующий раздел), в 2 м ниже C/T границы (см. pис. 2) [Snow et al., 2005]. Обе аномалии занимают временной интервал приблизительно 120 тыс. лет, что может соответствовать продолжительности интенсивного вулканизма. Аномальные интервалы обогащены менее летучими, более реакционноспособными элементами ( $\mathrm{Sc}, \mathrm{Co}, \mathrm{Mn}, \mathrm{Fe}$ ) и несколько менее обогащены более летучими, менее реакционноспособными элементами ( $\mathrm{Se}, \mathrm{Cd}, \mathrm{W}, \mathrm{Au}, \mathrm{Bi})$, что свидетельствует об их проксимальном положении по отношению к источнику металлов [Snow et al., 2005]. Верхнему пику металлов в Пуэбло соответствует пик отношений $\mathrm{Cr} / \mathrm{Al}$ в разрезе Истборн, расположенный в низах зоны Whiteinella archaeocretacea, на уровне окончания события похолодания Plenus [Pearce et al., 2009].

Сходная с наблюдающейся в Западном Внутреннем бассейне США двойная аномалия Ir (до 0.56 мг/т в пересчете на бескарбонатное вещество), а также $\mathrm{Sc}, \mathrm{Ti}, \mathrm{Cr}, \mathrm{Fe}$ и $\mathrm{Hf}$ выявлена на юге Центральной Колумбии, в толще черных сланцев верхнего сеномана [Orth et al., 1993]. Здесь отмечены также две добавочные аномалии металлов выше и ниже по разрезу. Теми же авторами опробовались многочисленные разрезы C/Т границы по всему земному шару. В разрезах Европы (Англии, Германии, Польши), а также в скважинах ODP/DSDP Атлантики и Тихого океана также обнаружены элементные аномалии, но они гораздо менее интенсивны, чем в Западном Внутреннем бассейне США и в Колумбии. Такой характер распределения аномалий показывает, что источник металлов находился в прото-Карибском регионе, Мексиканском заливе или Восточной Пацифике.

Многие исследователи связывают геохимические аномалии на С/T границе с образованием насыщенных металлами гидротермальных плюмов при формировании Карибского плато на востоке Тихого океана в 5000 км от Западного Внутреннего бассейна [Sinton, Duncan, 1997; Snow et al., 2005]. В этом случае анализы отложений, сформировавшихся в Экваториальной Пацифике в конце сеномана, также могли бы обнаружить аномалии металлов. Однако в скв. DSDP 585 и в известняках францисканского комплекса отмечены лишь слабые превышения концентраций элементов над локальным фоном. В частности, в скв. 585 в Восточно-Марианском бассейне (палеоширота $6^{\circ}$ ю.ш.) обнаружены слабые максимумы Sc, Ti, V, Cr и, возможно, Ir на контакте секций 2 и 3 керна 32, т. е. в 72 см выше слоя с наибольшим содержанием $\mathrm{C}_{\text {орг }}$ [Orth et al., 1993]. В связи с этим интересны повышенные содержания ряда элементов в углеродистых породах верхнего сеномана на п-ове Камчатский Мыс (Восточная Камчатка), отложившихся в условиях открытого океана на подводной вулканической возвышенности [Savelyeva et al., 2015]. По сравнению с вмещающими яшмами и известняками, углеродистые породы имеют более высокие содержания $\mathrm{Cu}, \mathrm{Ni}, \mathrm{Zn}, \mathrm{Ba}, \mathrm{V}, \mathrm{Mo}, \mathrm{U}, \mathrm{Ti}$, в том числе при нормировании к Al. В них также выявлены аномально высокие содержания $\mathrm{Au}, \mathrm{Ag}$, всех платиноидов и Re. Содержание Ir в минеральной части углеродистых пород 3.08 мг/т, Pt - 2176 мг/т [Savelyeva et al., 2015]. Концентрация всех этих элементов связана, по-видимому, с эвксинными условиями осадконакопления. В то же время зола углеродистых пород обогащена относительно яшм и известняков $\mathrm{Al}, \mathrm{Ti}, \mathrm{Mg}, \mathrm{K}$ и $\mathrm{Zr}$, причем сравнение соотношений этих элементов в углеродистых и вмещающих породах свидетельствует, что к фоновому поступлению обломочных и глинистых частиц примешивался материал из другого источника, скорее всего вулканического [Savelyeva et al., 2015]. Возможно, ряд элементов, сконцентрированных в богатом органикой осадке благодаря эвксинным условиям, поступил из ближнего и/или удаленного источника, связанного с вулканической и гидротермальной деятельностью. В целом распределение металлов вблизи С/Т границы в разрезах тихоокеанского региона изучено недостаточно.

В ограниченных морских системах поток металлов в осадок может превосходить поток из источника, связанного с обновлением глубинных вод [Tribovillard et al., 2006]. В разрезах, формирующихся в таких бассейнах, на интервале ОАЕ2 может наблюдаться снижение концентраций некоторых элементов в связи с истощением их запасов в водной толще. Например, на возвышенности Демерара, где ОВ накапливалось в осадках до, во время и после OAE2, как раз на интервале этого события содержания Мо, $\mathrm{V}$ и Zn падают, достигая минимальных значений, близких к коровым, на протяжении плато $\delta^{13} \mathrm{C}$ [Owens et al., 2016]. При этом уровень V понижается еще до позитивного изотопно-углеродного экскурса, что отражает глобальную экспансию вод с дефицитом кислорода (но не сульфидных). Понижение уровня Mo (низкие $\mathrm{Mo} / \mathrm{C}_{\text {орг }}$ ) совпадает с началом OAE2 и отражает глобальную экспансию эвксинных вод, глобальное отложение Мо и, следовательно, истощение глобального резервуара Мо. Низкие отношения $\mathrm{Mo} / \mathrm{C}_{\text {орг }}$ также регистрируются в многочисленных богатых $\mathrm{C}_{\text {орг }}$ разрезах ОАЕ2 в Западном Внутреннем бассейне США, Северной и Южной прото-Атлантике и океане Тетис.

Таким образом, аномальное распределение металлов в разрезах вблизи С/Т границы позволяет судить об условиях редокса как в локальном, так и в глобальном масштабе, а также в некоторых разрезах Западного Внутреннего бассейна США, Колумбии, Европы, Атлантики, Тихого океана дает указание на усиление вулканической и гидротермальной деятельности в конце сеномана. В том числе оно свидетельствует о двух крупных магматических импульсах - непосредственно перед OAE2 и в начале плато $\delta^{13} \mathrm{C}$. 


\section{ИЗОТОПНАЯ СТРАТИГРАФИЯ ИНТЕРВАЛА ОАЕ2}

В исследованиях разрезов, содержащих следы ОАЕ, применяются многочисленные изотопные показатели, чувствительные к изменениям гидротермального вклада в бассейн, скорости выветривания, а также к окислительно-восстановительным процессам. В ассоциации с изотопно-углеродным экскурсом на уровне OAE2 [Arthur et al., 1988] выявлены отчетливые сигналы изотопов Li [Pogge von Strandmann et al., 2013], Nd [MacLeod et al., 2008], Os [Turgeon, Creaser, 2008; Du Vivier et al., 2014; 2015b], Pb [Kuroda et al., 2007], Sr [Bralower et al., 1997; Jones, Jenkyns, 2001; Ando et al., 2009], U [Montoya-Pino et al., 2010], S [Adams et al., 2010; Owens et al., 2013], Ca [Blättler et al., 2011; Du Vivier et al., 2015a], Fe [Owens et al., 2012], Cr [Holmden et al., 2016; Wang et al., 2016]. Эти элементы имеют разные источники, а также разное время пребывания в океане, которое учитывается в сравнении с временем перемешивания океана около 1 тыс. лет [Broecker, Peng, 1982], хотя время пребывания некоторых элементов в меловом океане могло быть отличным от современного [Snow et al., 2005]. Изотопные системы этих элементов изучены в разной степени. В данной статье охарактеризованы изотопы, по которым получены наименее противоречивые результаты. Более всего существует данных по изотопии углерода.

Изотопы С. Время пребывания углерода в океане около 150 тыс. лет [Owens et al., 2013], что определяет гомогенный изотопно-углеродный состав океанов на длительных интервалах. Событие Бонарелли, отмеченное отложением морских черных (богатых органикой) осадков в глобальном масштабе, представляет собой крупное нарушение цикла углерода, затрагивающее как океан, так и атмосферу [Tsikos et al., 2004; Jarvis et al., 2006]. Оно характеризуется во всех частях Земли хорошо заметным позитивным изотопно-углеродным экскурсом, обычно $\sim 2-3$ \%о в морских карбонатах и наземном ОВ и $\sim 4-6$ \% в морском OB [Jenkyns et al., 2007]. Этот экскурс объясняется истощением резервуара растворенного $\mathrm{CO}_{2}$ легким углеродом $\left({ }^{12} \mathrm{C}\right)$ вследствие массового захоронения OB [Arthur et al., 1988]. Изотопно-углеродная стратиграфия $\left(\delta^{13} \mathrm{C}_{\text {орг }}\right.$ и $\left.\delta^{13} \mathrm{C}_{\text {карб }}\right)$ позволяет точно опознать слои, которые фиксируют OAE2, и дает стратиграфическую основу для изучения других изотопных систем на этом интервале. Амплитуда экскурса $\delta^{13} \mathrm{C}$ имеет региональные отличия, определяемые, в первую очередь, скоростью захоронения $\mathrm{C}_{\text {орг }}$. Например, на юге СПА, где в течение OAE2 были отложены огромные объемы черных сланцев, амплитуда позитивного экскурса $\delta^{13} \mathrm{C}_{\text {орг }}$ больше на $2 \%$, чем в других регионах [Arthur et al., 1988; Jenkyns et al., 2007; Jarvis et al., 2011]. Характер изменения $\delta^{13} \mathrm{C}_{\text {карб }}$ от среднесеноманского изотопного события (МСE) до ОАЕ2 сходен в Палеопацифике и Тетисе, что фиксируется во многих разpeзах мира, например, на Камчатке [Savelyev et al., 2012], в Италии [Coccioni, Galeotti, 2003] и Англии [Jenkyns et al., 1994] (рис. 3).

Начало ОАЕ2 определяется по основанию позитивного экскурса $\delta^{13} \mathrm{C}$. При корреляции разрезов обычно используются характерные стратиграфические уровни А, В и С на кривой $\delta^{13} \mathrm{C}$. Уровень А отвечает последнему относительно деплетированному значению $\delta^{13} \mathrm{C}$ перед первым значительным сдвигом к позитивным значениям; В маркирует небольшой интервал деплетированных значений, следующий за позитивным экскурсом $\delta^{13} \mathrm{C}$; C отвечает последнему относительно обогащенному значению перед возвратом $\delta^{13} \mathrm{C}$ к значениям перед OAE2 [Tsikos et al., 2004; Du Vivier et al., 2015b] (см. pис. 2). Иногда говорят о двух пиках на кривой $\delta^{13} \mathrm{C}$ в позднем сеномане и разделяющем их небольшом понижении, соответствующем событию похолодания Plenus. За этими пиками следует плато (длительные высокие значения $\delta^{13} \mathrm{C}$ в относительно мелководных разрезах (Истборн, Пуэбло)) или быстрое понижение значений в более глубоководных разрезах (Манильва, Фурло). Нередко в глубоководных разрезах и второй пик $\delta^{13} \mathrm{C}$ идентифицируется с трудом. Такие различия могут быть связаны с изменениями региональной продуктивности или перерывами в осадконакоплении [Tsikos et al., 2004; Mort et al., 2007b]. B стратотипе С/Т границы в районе Пуэбло (Колорадо) начало ОАЕ2 резкое, но окончание более постепенное и трудноопределимое. Поэтому даже здесь, в стратотипе, оценки продолжительности OAE2, основанные на радиометрическом датировании бентонитовых прослоев и астрохронологии, сильно различаются. По последним данным, продолжительность позитивного экскурса $\delta^{13} \mathrm{C} \sim 600$ тыс. лет [Tsikos et al., 2004; Sageman et al., 2006]. Абсолютный возраст начала OAE2, определенный в районе Пуэбло, $\sim 94.38 \pm 0.15$ млн лет [Meyers et al., 2012]. В разрезе группы Эзо на о. Хоккайдо U-Pb возраст цирконов из туфовых прослоев вместе с изотопией углерода и осмия дал возможность определить продолжительность OAE2 также в 600 тыс. лет и абсолютное время начала этого события $94.44 \pm 0.14$ млн лет. Таким образом установлена синхронность проявления ОАЕ в Западном Внутреннем бассейне и в Японии [Du Vivier et al., 2015b].

Некоторые исследователи указывают на присутствие на фоне позитивного экскурса кратковременного негативного пика на кривых $\delta^{13} \mathrm{C}_{\text {орг }}$ и $\delta^{13} \mathrm{C}_{\text {карб }}$ в разрезах Центральной Италии, Южной Англии, юго-востока Северной Атлантики, Японии и Западного Внутреннего бассейна США [Kuroda et al., 2007]. Этот негативный сдвиг $\delta^{13} \mathrm{C}$ связывают с привносом изотопно-легкого углерода в систему океан-атмосфера. Носителями легкого углерода могли быть диоксид углерода, выделяющийся из мантии при вулканической дегазации, или метан, высвобождающийся из газогидратов. Сходный кратковремен- 


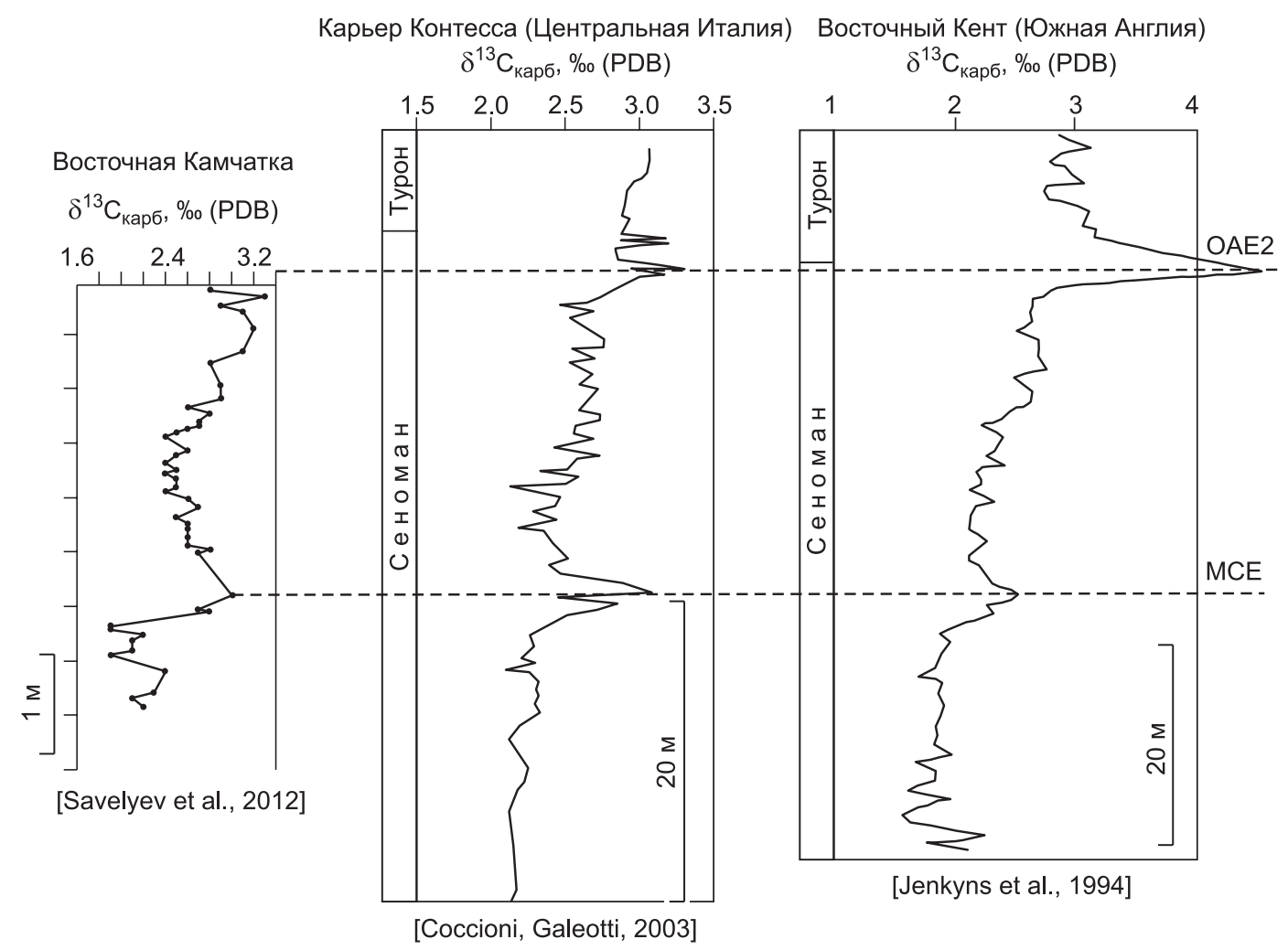

Рис. 3. Фрагменты типичных кривых $\delta^{13} \mathrm{C}_{\text {карб }}$ на интервале от МСЕ до ОАЕ2.

ный негативный пик обнаружен в разрезе Таппу на о. Хоккайдо [Nemoto, Hasegawa, 2011]. Эти авторы сопоставляют данный пик с отрицательными экскурсами в других разрезах земного шара более осторожно. Тем не менее они предполагают, что возможна корреляция этого пика с экскурсами на кривых $\delta^{13} \mathrm{C}_{\text {орг }}$ в разрезах Чебрара (Центральная Италия), Истборн и Пуэбло.

Кроме соотношения тяжелого и легкого изотопов углерода, в событийной стратиграфии используется величина $\Delta^{13} \mathrm{C}$ - разность между $\delta^{13} \mathrm{C}$ карбоната и $\delta^{13} \mathrm{C}$ морской органики. При повышении парциального давления $\mathrm{CO}_{2}$ в атмосфере и доступности его в поверхностных водах фитопланктон сильнее фракционирует изотопы углерода, значения $\delta^{13} \mathrm{C}$ при этом становятся более негативными. Поэтому $\Delta^{13} \mathrm{C}$ является хорошим показателем $p_{\mathrm{CO}_{2}}$ [Jarvis et al., 2011]. Для этой же цели используются $\delta^{13} \mathrm{C}$ различных компонентов фитопланктона [Sinninghe Damsté et al., 2008]. Применительно к OAE2 эти методы показали, что в позднем сеномане $p_{\mathrm{CO}_{2}}$ увеличивалось, первому пику $\delta^{13} \mathrm{C}$ соответствует его снижение, а затем $p_{\mathrm{CO}_{2}}$ снова постепенно увеличивается вплоть до раннего турона. Такая закономерность проявляется во многих разрезах по всему миру.

Кривые $\delta^{13} \mathrm{C}$ наземной органики также могут расходиться с кривыми для карбонатов. Это связано с разнообразными региональными и глобальными факторами, в первую очередь с составом наземной растительности [Kuypers et al., 1999]. Например, в Японии значения $\delta^{13} \mathrm{C}$ наземного $\mathrm{C}_{\text {орг }}$ обнаруживают негативный тренд на протяжении верхнего сеномана. Это может быть связано с повышением влажности и распространением густых лесов. При теневом фотосинтезе значения $\delta^{13} \mathrm{C}$ в листьях растений имеют выраженный вертикальный градиент, поэтому понижаются значения $\delta^{13} \mathrm{C}$ органики, производимой этими растениями [Hasegawa, 2003].

В целом можно сказать, что, несмотря на некоторые региональные отличия, изотопно-углеродные данные могут служить надежной основой для выделения уровня OAE2 и прослеживания его в разрезах по всему земному шару.

Изотопы Sr. Соотношения изотопов $\mathrm{Sr}$ в древних океанах фиксируются в карбонатных и фосфатных осадках. В любой момент это соотношение в океане гомогенно, так как время пребывания $\mathrm{Sr}$ ( $\sim 5$ млн лет) гораздо больше, чем время перемешивания океана [Snow et al., 2005]. На основе базы данных по изотопным отношениям $\mathrm{Sr}\left({ }^{87} \mathrm{Sr} /{ }^{86} \mathrm{Sr}\right)$ хорошо сохранившихся и хорошо датированных морских осадков была построена и в дальнейшем усовершенствована кривая для последних 590 млн лет геологической истории [McArthur et al., 2012]. В конце сеномана кривая изотопов Sr испытывает отклонение 
к более низким (нерадиогенным) значениям, начало которого приблизительно коррелирует с OAE2. Негативный экскурс гораздо шире, чем интервал ОАЕ2, это объясняется большим временем пребывания $\mathrm{Sr}$ в океане. Минимальные значения ${ }^{87} \mathrm{Sr} /{ }^{86} \mathrm{Sr}$ достигаются в туроне, прежние значения восстанавливаются в сантоне. Уменьшение ${ }^{87} \mathrm{Sr} /{ }^{86} \mathrm{Sr}$ означает, что поступление гидротермального $\mathrm{Sr}\left({ }^{87} \mathrm{Sr} /{ }^{86} \mathrm{Sr} \approx 0.703\right)$ в это время возрастало по отношению к поступлению $\mathrm{Sr}$ с континентов ( ${ }^{87} \mathrm{Sr} /{ }^{86} \mathrm{Sr} \approx 0.712$ ) [Bralower et al., 1997]. Сдвиг изотопных значений мог быть вызван тремя способами: 1) сокращение речного привноса радиогенного $\mathrm{Sr}$ из выветривающейся континентальной коры; 2) понижение отношения ${ }^{87} \mathrm{Sr} /{ }^{86} \mathrm{Sr}$ в речных водах; 3) привнос нерадиогенного Sr из подводных гидротерм. На основе моделирования с учетом истории морских температур, уровня моря, площади суши, вулканизма на океанических плато и в срединно-океанических хребтах (COX) было показано, что наиболее вероятен третий сценарий [Jones, Jenkyns, 2001]. Одни исследователи считают источником избыточного нерадиогенного Sr внутриплитный вулканизм, конкретно в случае OAE2 чаще всего указывают на Карибское плато [Snow et al., 2005], другие же считают, что форма кривой не вполне соответствует импульсам внутриплитного вулканизма, и источником нерадиогенного $\mathrm{Sr}$, скорее, были гидротермальные системы СОХ в периоды их перестройки или резкого увеличения скорости спрединга [Bralower et al., 1997; Jones, Jenkyns, 2001]. Третьи допускают оба источника ${ }^{86} \mathrm{Sr}$ [Jenkyns, 2010]. Совпадение экскурса ${ }^{87} \mathrm{Sr} /{ }^{86} \mathrm{Sr}$ с отложением черных сланцев рассматривается как свидетельство причинной связи между мантийным плюмовым вулканизмом и OAE2 [Sinton, Duncan, 1997; Leckie et al., 2002; Snow et al., 2005]. Однако начало сдвига ${ }^{87} \mathrm{Sr} /{ }^{86} \mathrm{Sr}$ может предварять OAE2 примерно на $>0.6$ млн лет. В связи с этим высказано предположение, что вулканизм и вызванные им глобальные изменения могли подготовить климатический и океанский режимы к ОАЕ2, но не были непосредственными инициаторами события [Jones, Jenkyns, 2001; Ando et al., 2009].

В некоторых разрезах на фоне общего снижения значений ${ }^{87} \mathrm{Sr} /{ }^{86} \mathrm{Sr}$ в начале OAE2 было зафиксировано кратковременное увеличение радиогенного стронция. Этот пик объясняется повышенным выветриванием силикатов, связанным с ускорением гидрологического цикла [Frijia, Parente, 2008; Jenkyns, 2010; Jarvis et al., 2011].

Изотопы Os. Изотопный состав осмия морской воды отражает смешивание радиогенного осмия, поступающего из древней континентальной коры при ее выветривании $\left({ }^{187} \mathrm{Os} /{ }^{188} \mathrm{Os} \approx 1.4\right)$, и нерадиогенного осмия из мантийного, гидротермального и внеземного источников $\left({ }^{187} \mathrm{Os} /{ }^{188} \mathrm{Os} \approx 0.12\right)$. Короткое время пребывания Os в морской воде (до 10 тыс. лет) дает возможность глобальной корреляции разрезов OAE2 по изотопному составу Os. Выяснилось, что профиль ${ }^{187} \mathrm{Os} /{ }^{188} \mathrm{Os}$ имеет очень сходную форму для разрезов, формировавшихся по всему миру в различных обстановках - в расширяющейся протоАтлантике, на пелагическом шельфе Европы, в Западном Внутреннем бассейне, в преддуговом прогибе Японии (группа Эзо), на окраине континента в Калифорнии (формация Баден Каньон). Значения ${ }^{187} \mathrm{Os} / 188 \mathrm{Os}$ относительно радиогенные $(\sim 0.55-1.00)$ перед OAE2, примерно за 23 тыс. лет до начала OAE2 (т. е. до начала позитивного экскурса $\left.\delta^{13} \mathrm{C}\right)$ они резко становятся нерадиогенными $(\sim 0.20-0.30)$, а затем постепенно возвращаются к более радиогенным ( $\sim 0.70)$ (обычно после уровня В изотопно-углеродной кривой). Такой тренд в начале ОАЕ2 требует увеличения в $30-50$ раз потока нерадиогенного ${ }^{188} \mathrm{Os}$ в океаны. Таким источником мог быть вулканизм крупных магматических провинций [Turgeon, Creaser, 2008; Du Vivier et al., 2014, 2015b].

В разрезах, где большое влияние имел континентальный снос (группа Эзо, Баден Каньон и в особенности Западный Внутренний бассейн), примерно за 80 тыс. лет до ОАЕ2 наблюдаются более радиогенные значения ${ }^{187} \mathrm{Os} /{ }^{188} \mathrm{Os}$, чем в разрезах открытого океана [Du Vivier et al., 2014, 2015b] (см. рис. 2). На профили ${ }^{187} \mathrm{Os} /{ }^{188} \mathrm{Os}$ на интервалах перед OAE2 в приконтинентальных разрезах повлияло сразу несколько факторов: ускоренное выветривание, изменение уровня океана и открытости бассейна; на все это могли накладываться и импульсы вулканизма в магматических провинциях. В начале OAE2 привнос нерадиогенного Os стал преобладать над другими факторами, что и определило близость профилей ${ }^{187} \mathrm{Os} /{ }^{188} \mathrm{Os}$ в C/T разрезах по всему миру [Jenkyns, 2010; Du Vivier et al., 2014]. В тихоокеанских разрезах увеличение нерадиогенного Оs датировано $94.44 \pm 0.14$ и $94.28 \pm 0.25$ млн лет назад (вблизи начала OAE2) [Du Vivier et al., 2015b].

Изотопы Nd. Неодим имеет короткое время пребывания в океане (около 500 лет), поэтому относительный вклад $\mathrm{Nd}$ из древнего континентального и молодого вулканогенного материала отличается в различных бассейнах. Это позволяет использовать изотопы $\mathrm{Nd}$ для выяснения характера океанской циркуляции в прошлом. Отношение изотопов неодима морской воды выражают в единицах $\varepsilon_{\mathrm{Nd}}$ [Pucéat, 2008]. Рыбные остатки (фосфатные зубы и кости) сохраняют изотопный состав $\mathrm{Nd}$ морской воды, поскольку они активно сорбируют этот элемент из окружающей воды на дне во время отложения и устойчивы к позднейшему диагенетическому изменению [Zheng et al., 2013].

Данных по изотопам $\mathrm{Nd}$ для мелового периода еще недостаточно, чтобы полностью восстановить океанскую циркуляцию в это время. Однако известно, что наибольшие значения $\varepsilon_{\mathrm{Nd}}$ (от 0 до -6) характерны для Тихого океана, в прото-Атлантическом и прото-Индийском океанах они находятся в диапазо- 
не от -4 до -11 , и наименьшие значения (до -18) зафиксированы на возвышенности Демерара [Moiroud et al., 2013]. В случае Тихого океана это связано с размывом островных дуг и проявлениями вулканизма, в остальных случаях бо́льшую роль играет поступление $\mathrm{Nd}$ при размыве континентальной коры.

Характер изменения $\varepsilon_{\mathrm{Nd}}$ на интервале OAE2 наиболее изучен в атлантических разрезах. Скважина 1050 ODP на протяжении интервала OAE2 обнаруживает значения $\varepsilon_{\mathrm{Nd}}$, близкие к тихоокеанским, а затем в позднем мелу значения становятся обычными для Атлантики и Тетиса [MacLeod et al., 2008]. Ha возвышенности Демерара на интервале OAE2 обнаружено два сильных позитивных экскурса: первый в основании OAE2, он едва заметно опережает позитивный сдвиг $\delta^{13} \mathrm{C}$; второй в середине OAE2, он совпадает с эпизодом похолодания [Zheng et al., 2013]. Данные экскурсы могут объясняться: 1) уменьшением регионального континентального сноса или изменением значений $\varepsilon_{\mathrm{Nd}}$ в сносимом материале; 2) привносом из нового источника с необычным значением $\varepsilon_{\mathrm{Nd}}$, каковым могут быть извержения в крупных магматических провинциях; 3) изменениями в океанской циркуляции [MacLeod et al., 2008]. Первый вариант был отвергнут исследователями, поскольку первый экскурс $\varepsilon_{\mathrm{Nd}}$ приходится на эпизод повышенных температур, во время которого континентальный снос должен был увеличиться [Martin et al., 2012], что и подтверждается другими изотопными системами, например $\mathrm{Sr}$ [Jarvis et al., 2011]. К тому же во время OAE2 в Атлантике отсутствовали континентальные окраины с высокими значениями $\varepsilon_{\mathrm{Nd}}$. По поводу двух других механизмов возникновения данных экскурсов мнения исследователей разделились. Одни из них считают более вероятным замещение во время ОАЕ2 сильнонерадиогенных придонных вод, характерных для района Демерары, более радиогенными водами, поступающими из океана Тетис и Северной Атлантики [Martin et al., 2012]. Это могло произойти либо вследствие повышенного испарения и ускоренного формирования глубинных вод в Тетическом регионе, либо из-за распреснения Южно-Американского межконтинентального пролива (между Южной Америкой и Африкой) и уменьшения плотности придонных вод Демерары. Другие исследователи связывают поступление радиогенного $\mathrm{Nd}$ с двумя импульсами вулканизма, возможно, в Арктической или Карибской крупных магматических провинциях [Zheng et al., 2013]. В частности, дискутируется возможность дальней транспортировки вулканогенного $\mathrm{Nd}$, которая возможна только аноксидными водами, в противном случае $\mathrm{Nd}$ был бы связан в оксидах $\mathrm{Fe}$ и $\mathrm{Mn}$ вблизи своего источника. В пользу вулканического происхождения позитивного экскурса изотопов $\mathrm{Nd}$ является совпадение его стратиграфической позиции со слоями, обогащенными следовыми металлами, в морских разрезах Северной Атлантики [Orth et al., 1993; Pearce et al., 2009].

Изотопы S. Сера поступает в океан в результате выветривания сульфид- и сульфатсодержащих минералов континентальных пород, а также вулканической/гидротермальной деятельности. Величины этих потоков изменяются во времени и в пространстве, но их изотопные черты $\left(\delta^{34} S\right)$ сходны и заключены в относительно узком диапазоне 0-8 \% [Owens et al., 2013]. В настоящее время речные воды имеют среднее значение $\delta^{34} \mathrm{~S} \sim 6 \%$ о, гидротермы $\sim 3-3.5 \%$ [Adams et al., 2010]. Время пребывания $\mathrm{S}$ в океане около 2 млн лет [Owens et al., 2013]. Сера удаляется из океанских вод при осаждении и захоронении гипса и других сульфатов, а также органических соединений и пирита. Наибольшее изотопное фракционирование $\mathrm{S}$ происходит при образовании пирита: сульфатредуцирующие бактерии, восстанавливая сульфат до сероводорода, обогащают последний легким изотопом ${ }^{32} \mathrm{~S}$. Остаточный сульфатный резервуар развивается при этом в сторону обогащенных ${ }^{34} \mathrm{~S}$ значений. Пирит, образующийся впоследствии из этого эволюционирующего резервуара, будет постепенно обогащаться ${ }^{34} \mathrm{~S}-$ тем медленнее, чем больше концентрация сульфата в морской воде. Поэтому при большем уровне сульфата будет больше изотопный контраст между сульфатной и сульфидной серой $\Delta^{34} S\left(\delta^{34} \mathrm{~S}_{\text {сульфата }}-\delta^{34} \mathrm{~S}_{\text {пирита }}\right)$.

В стратиграфических исследованиях обычно измеряют значения $\delta^{34} \mathrm{~S}$ сульфатов, замещающих карбонат-ионы в кристаллической решетке карбонатов, и/или значения $\delta^{34} \mathrm{~S}$ пирита, а также вычисляют $\Delta^{34} \mathrm{~S}$. На уровне OAE2 в различных разрезах (Западный Внутренний бассейн США, Центральная и Южная Италия, Англия) обнаружены позитивные экскурсы $\delta^{34} \mathrm{~S}_{\text {сульфата }}$ [Ohkouchi et al., 1999; Adams et al., 2010; Owens et al., 2013]. Они согласуются с увеличением скорости захоронения пирита, осаждающегося в эвксинных условиях. Изотопно-углеродный пик предваряет пик изотопов $\mathrm{S}$ на несколько сотен тысяч лет. Моделирование наблюдаемых изотопных экскурсов С и $\mathrm{S}$ показало, что скорость захоронения $\mathrm{S}$ в течение OAE2 возросла в 15-40 раз по сравнению с настоящим временем. Это может означать, что настолько же увеличилась максимальная площадь распространения эвксинных придонных вод, составив во время ОАЕ2 2.5-7.0\% морского дна [Owens et al., 2013].

В разрезе Западного Внутреннего бассейна США в районе Пуэбло $\delta^{34} \mathrm{~S}_{\text {сульфата }}$ имеет $\sim 5 \%$ негативный сдвиг за $\sim 500$ тыс. лет перед OАЕ2. В том же разрезе $\Delta^{34} \mathrm{~S}$ увеличивается начиная с $\sim 500$ тыс. лет перед OAE2, достигает максимальных значений в начале аноксического события и уменьшается в течение OAE2 [Adams et al., 2010] (см. рис. 2). Указанные авторы связывают наблюдаемые тренды с поступлением дополнительного сульфата из вулканического/гидротермального источника. Об этом же может свидетельствовать то, что профиль $\delta^{34} \mathrm{~S}_{\text {пирита }}$ на возвышенности Демерара [Hetzel et al., 2009], в Западном Внутреннем бассейне США [Adams et al., 2010], в бассейне Тарфайя [Poulton et al., 2015] и в Мек- 
сике [Núñez-Useche et al., 2016] достигает минимального значения на разных уровнях перед и во время OAE2 и постепенно возвращается к более высоким значениям после этого события. Необходимо отметить, что поступление сульфата может происходить и в связи с ускоренным континентальным выветриванием. Моделирование показывает, что необходимое для изотопного сдвига содержание сульфата может быть достигнуто увеличением вулканического вклада $\mathrm{S}$, вклада выветривания или и того, и другого вместе [Poulton et al., 2015].

Изотопы Fe. В кислородных и субоксидных шельфовых обстановках вместе с диагенетической реминерализацией углерода происходит восстановление оксидных фаз $\mathrm{Fe}$, в результате в поровые и придонные воды высвобождается предпочтительно изотопно легкое $\mathrm{Fe}$. Оставшееся в осадке осадочное $\mathrm{Fe}$, соответственно, имеет бо́льшие значения $\delta^{56} \mathrm{Fe}$. Легкое $\mathrm{Fe}$ перемещается в растворенном виде; в эвксинных обстановках оно входит в пирит, образующийся в водной толще, и затем уходит в осадки.

Таким образом, при отсутствии сильного гидротермального вклада в кислородных обстановках $\mathrm{Fe} / \mathrm{Al}$ уменьшается, а $\delta^{56} \mathrm{Fe}$ увеличивается, в эвксинных же обстановках $\mathrm{Fe} / \mathrm{Al}$ увеличивается, а $\delta^{56} \mathrm{Fe}$ уменьшается.

Гидротермальный вклад $\mathrm{Fe}$ можно выявить, пользуясь теми же показателями. Осадки, содержащие $\mathrm{Fe}$ из гидротермального источника, имеют узкий диапазон значений $\delta^{56} \mathrm{Fe}$, сходный со средним изотопным составом магматических пород (от $\sim 0$ до $-0.5 \%$ ), но обнаруживают широкий диапазон повышенных отношений $\mathrm{Fe} / \mathrm{Al}$.

Можно также отличить обломочный вклад от гидротермального: в первом случае значения $\mathrm{Fe} / \mathrm{Al}$ будут около 0.5 (Fe/Al среднее для континентальной коры [Taylor, McLennan, 1995]), во втором случае - гораздо выше, чем 0.5 [Owens et al., 2012].

Применение этих критериев к данным из разрезов бассейна Тарфайя, Истборна и ряда скважин CПА на интервалах OAE2 выявило вклады Fe из различных источников. Было установлено существование переноса $\mathrm{Fe}$ с кислородных шельфов северной части этого бассейна на высокопродуктивные аноксидные шельфы южных приэкваториальных его частей. Кроме того, в южной части СПА были обнаружены свидетельства повышенного гидротермального привноса $\mathrm{Fe}$ - в связи с ускоренным спредингом или формированием крупных магматических провинций [Owens et al., 2012].

Изотопы U. Вариации изотопного отношения ${ }^{238} \mathrm{U} /{ }^{235} \mathrm{U}\left[\delta^{238} \mathrm{U}\right]$ являются показателями палеоредокса. Они могут быть использованы для определения распространения морской аноксии в геологическом прошлом. Уран поступает в океаны в связи с выветриванием континентальной коры. Захоронение $\mathrm{U}$ в осадках ассоциирует с изотопным фракционированием ${ }^{238} \mathrm{U}$ и ${ }^{235} \mathrm{U}$, которое особенно велико (до $\sim 1 \% \delta^{238} \mathrm{U}$ ) в аноксидных обстановках (в кислородной, субоксидной среде и в гидротермальных отложениях изотопное фракционирование гораздо меньше). Во время восстановления U в аноксидных и эвксинных условиях в осадок уходят более тяжелые изотопы, а более легкие остаются в воде.

Современное время пребывания U в океане $~ 500$ тыс. лет. В настоящее время большая часть урана осаждается в дизоксидных обстановках. Напротив, во время ОАЕ большая часть урана осаждалась в аноксидных и эвксинных обстановках. Поэтому черные сланцы, отлагавшиеся во время ОАЕ, имеют более легкие характеристики изотопов U, чем их современные аналоги [Montoya-Pino et al., 2010]. Сравнивая изотопные отношения U черных сланцев на интервале OAE2 возвышенности Демерара и современных черноморских черных сланцев, эти авторы подсчитали, что удаление U в аноксидные осадки во время OAЕ2 возросло примерно в три раза относительно современных. Соответственно, распространенность аноксидных и эвксинных обстановок увеличилась во время этого события, по крайней мере, в три раза по сравнению с настоящим временем и могла составлять до $\sim 1-2 \%$.

Таким образом, изменения изотопных соотношений рассмотренных элементов на уровне события Бонарелли часто интерпретируются как указывающие на увеличение интенсивности магматизма и гидротермальной деятельности в это время. Наиболее обоснована такая трактовка для изотопных систем $\mathrm{Sr}$ и Os и, возможно, Fe. Для изотопных экскурсов $\mathrm{Nd}$ и $\mathrm{S}$, а также для отрицательного экскурса $\delta^{13} \mathrm{C}$ существуют и другие объяснения. Кроме того, для уверенной интерпретации данных по изотопии $\mathrm{Nd}$ необходимо получение таких данных из большего числа разрезов С/Т граничного интервала. Второстепенные пики радиогенного $\mathrm{Sr}$ и, возможно, изотопные сдвиги $\mathrm{S}$ могут указывать на увеличение континентального выветривания в начале ОАЕ2.

\section{ВОЗРАСТ ВУЛКАНИЗМА В НЕКОТОРЫХ КРУПНЫХ МАГМАТИЧЕСКИХ ПРОВИНЦИЯХ}

Поскольку многие данные хемостратиграфии указывают на связь события Бонарелли с вулканизмом, мы можем, приняв датировки начала ОАЕ2 около $94.38 \pm 0.15$ млн лет [Meyers et al., 2012] и $94.44 \pm 0.14$ млн лет [Du Vivier et al., 2015b], оценить, насколько они согласуются со временем магматической деятельности в различных магматических провинциях. 
Плато Онтонг-Джава. Онтонг-Джава, Манихики и Хикуранги образовались как одно крупное суперплато 125 млн лет назад и впоследствии были разделены в процессе спрединга [Nakanishi et al., 2015]. Возраст базальтов определялся по образцам, извлеченным из скважин DSDP и ODP, поднятым при драгировании, а также отобранным на Соломоновых островах из обдуцированных блоков. На плато Онтонг-Джава выделяются два значительных по объему платообразующих магматических события $122 \pm 3$ и $90 \pm 4$ млн лет назад (первое событие значительно крупнее второго), а также более поздние эпизоды [Mahoney et al., 1993, 2001; Tejada et al., 1996]. Между 122 и 90 млн лет вулканизм не прекращался полностью. Так, в скв. 288 DSDP интервал вулканокластики имеет возраст от среднего сеномана до коньяка, а в скв. 289 обнаружены аналогичные породы аптского-альбского возраста. Близкая к началу OAE2 датировка получена по монофракции наиболее свежего полевого шпата в скв. 803 - 93.6 млн лет [Mahoney et al., 1993]. В скв. 1185 ODP известковые нанофоссилии из известняков между базальтовыми потоками в верхних 15 м основания дают возраст в пределах от альба до верхов сеномана, т. е. базальты изливались в интервале между 93 и 112 млн лет.

Карибская провинция. Породы, формировавшие Карибское плато, ныне выходят на поверхность на о. Гаити, в складчатых комплексах на северо-западе Южной Америки и в прилегающих районах Центральной Америки. Также они вскрыты скважинами DSDP в Карибском море. Частью Карибской магматической провинции считаются и магматические комплексы вдоль тихоокеанского побережья Центральной Америки (Коста-Рика). Большую часть магматического фундамента Коста-Рики слагают комплексы, формировавшиеся между 95 и 75 млн лет (Ar-Ar возраст) [Hauff et al., 2000]. На Гаити получены датировки по Ar-Ar, близкие по времени к началу OAE2: 95.12 $\pm 1.44 ; 94.36 \pm 0.63 ; 94.43 \pm 0.66$ млн лет [Snow et al., 2005]. Главный импульс платобазальтового магматизма в Карибской провинции приходится на 94.7-83.2 млн лет. Имеются также более молодые и более древние датировки, расширяющие возрастной диапазон вулканизма в Карибской провинции до 70 млн лет (69-139 млн лет) [Нoernle et al., 2004]. Это позволило указанным авторам предположить, что рассматриваемые магматические комплексы представляют не одно, а множество плато, а также остатки ранней истории Галапагосской горячей точки, которые были аккретированы в процессе субдукции.

Подводные горы на западе Тихого океана. Проявления тихоокеанского внутриплитного магматизма в середине мелового периода имели место не только на плато Онтонг-Джава и Карибском, но также и на некоторых подводных горах, в настоящее время расположенных в Западной Пацифике. Например, имеются датировки базальтов в диапазоне от середины мела до палеогена, полученные для Магеллановых гор (от $\sim 121$ до 74 млн лет), гор Маркус-Уэйк (от 122 до 63.5 млн лет) и подводных гор северной части цепи Маршалловых островов (от $\sim 140$ до 230 млн лет) [Седов и др., 2005 и ссылки в этой работе]. Некоторые из этих датировок весьма близки к началу OAE2. В скв. 872 ODP вблизи Маршалловых островов над базальтовым основанием залегают осадки нижнего сантона, указывая на время прекращения вулканизма конкретно на гайоте Ло-Ен [Premoli Silva et al., 1993]. На п-ове Камчатский Мыс (Восточная Камчатка) потоки базальтов и гиалокластиты переслаиваются с альб-сеноманскими пелагическими яшмами и известняками, которые формировались на поверхности симаунта в центральной части Тихого океана. Слой гиалокластитов, залегающий здесь непосредственно над углеродистым прослоем, соответствующим OAE2, а также примесь вулканогенного материала в самом углеродистом прослое указывают на вулканизм, происходивший в это время [Савельева, 2009]. Наличие в составе данной ассоциации щелочных базальтов и обогащенных толеитов, сходных по геохимическим характеристикам с породами подводной горы Детройт, свидетельствует о влиянии Гавайского мантийного плюма на формирование офиолитового комплекса п-ова Камчатского Мыса [Савельев, 2004; Portnyagin et al., 2008].

Арктическая провинция. Свидетельства магматической и гидротермальной деятельности Арктической провинции обнаруживаются на островах Шпицберген и Земля Франца-Иосифа, на прилегающих шельфах, островах Аксель-Хейберг и Элсмир и, возможно, в Северной Гренландии [Tarduno, 1998]. Магматизм в этой провинции был длительным и включал толеитовую фазу (130-80 млн лет) и более позднюю щелочную фазу (85-60 млн лет). Образование толеитов было связано с раскрытием Канадского бассейна, но могло включать в себя и действие мантийного плюма. Эпизод наиболее молодого толеитового магматизма (100-80 млн лет, преобладают датировки сеноманские и туронские, есть также кампанские) ограничен северной частью Канадского арктического архипелага [Tegner et al., 2011]. В том числе на о. Аксель-Хейберг имеется $\mathrm{Ar}-\mathrm{Ar}$ датировка, близкая к началу OAE2: $95.3 \pm 0.2$ млн лет [Tarduno, 1998].

Плато Кергелен и хр. Брокен. Материал для изучения этой провинции поступил из скважин ODP. Образование крупной магматической провинции Кергелен произошло после раскола между Индией и Антарктидой, с $\mathrm{Ar} / \mathrm{Ar}$ возрастами извержений, омолаживающимися с юга на север в диапазоне от $\sim 19$ млн лет на южном плато Кергелен до $\sim 34$ млн лет на северном плато Кергелен. Пики магматизма происходили в интервалах 119-110 и 105-95 млн лет [Frey et al., 2003]. До начала сеномана значи- 
тельная часть провинции находилась над уровнем моря. Хребет Брокен граничил с центральным плато Кергелен до эоцена, он формировался от 100 до 95 млн лет.

Мадагаскарская провинция континентальных платобазальтов. На Мадагаскаре в верхнем мелу широко распространены базальты и риолиты. Их относят к следу горячей точки Марион, которая в позднем мелу располагалась на юго-востоке Мадагаскара. Этот магматизм был связан с разделением Мадагаскара и Индии. Здесь проявлялся в основном субаэральный вулканизм. Ранние датировки $\mathrm{K}-\mathrm{Ar}$ методом давали широкий спектр возрастов: от 31 до 97 млн лет. Высокоточные Ar-Ar определения возраста выявили, что вулканические породы и дайки рифтовой восточной окраины Мадагаскара сформировались не более, чем за 6 млн лет, с самой древней датировкой 90.7 млн лет и взвешенным средним $87.6 \pm 0.6$ млн лет [Storey et al., 1995]. Немного расширяет этот диапазон точный U-Pb возраст по циркону-бадделеиту с севера-востока Мадагаскара $91.6 \pm 0.3$ млн лет [Torsvik et al., 1998]. Однако вулканическое основание протяженного подводного Мадагаскарского хребта остается неопробованным и недатированным [Kuroda et al., 2007].

Итак, по имеющимся данным, начало события Бонарелли совпадает по времени с умеренным вулканизмом на плато Онтонг-Джава в промежутке между двумя главными импульсами. Извержения на ряде подводных гор Западной Пацифики происходили в широком временном диапазоне, захватывающем и поздний сеноман. Непосредственно предшествует началу OAE2 начало главного импульса платобазальтового магматизма в Карибской провинции и окончание крупного пика магматизма на плато Кергелен и хр. Брокен. В это же время происходил активный толеитовый магматизм в Арктической провинции, длившийся с начала сеномана по кампан. Вулканизм в Мадагаскарской провинции начался уже в туроне. Однако отсутствие обнажений часто препятствует восстановлению истории извержений, поэтому как на Мадагаскаре, так и в других провинциях возрастной диапазон магматизма может расширяться и уточняться.

\section{СВЯЗЬ СОБЫТИЯ БОНАРЕЛЛИ С ВУЛКАНИЗМОМ}

Многие исследования подчеркивают роль извержений крупных магматических провинций и сопутствующей гидротермальной деятельности в возникновении ОАЕ и синхронность этих явлений [Larson, 1991; Orth et al., 1993; Sinton, Duncan, 1997; Jones, Jenkyns, 2001; Leckie et al., 2002; Snow et al., 2005; Kuroda et al., 2007; Turgeon, Creaser, 2008; Adams et al., 2010; Du Vivier et al., 2014, 2015b]. Интенсивные извержения имели различные последствия: 1) выделение $\mathrm{CO}_{2}$ в атмосферу и потепление, повысившие скорость выветривания и, следовательно, поступление в океан питательных веществ [Jones, Jenkyns, 2001; Jenkyns, 2010; Pogge von Strandmann et al., 2013]; 2) гидротермальный вынос в океаны огромного количества восстановленных металлов и сульфидов, которые расходовали кислород морской воды на свое окисление и служили питательными веществами для фитопланктона [Sinton, Duncan, 1997; Zheng et al., 2013]; 3) вулканогенный апвеллинг, выносящий на поверхность океана дополнительные питательные вещества [Price, 2003]. Увеличение доступности лимитирующих питательных веществ и $\mathrm{CO}_{2}$ стимулировало первичную продуктивность, ведущую к расходованию кислорода на разложение ОВ и установлению аноксии в обширных частях океанов [Bralower, 2008; Trabucho-Alexandre et al., 2010].

Конкретные механизмы воздействия вулканизма на среду в конце сеномана являются предметом дискуссий. Пока неизвестно, что больше влияет на биопродуктивность: поступление питательных веществ в океаны непосредственно из вулканов и гидротерм или поступление их с суши в связи с ускорением гидрологического цикла и более интенсивным выветриванием. Некоторые исследователи считают источником питательных веществ реакции обмена между водой и породой при гидротермальном изменении океанских платобазальтов [Snow et al., 2005]. Однако описание и количественная оценка гидротермальных систем, связанных с вулканизмом океанских плато, остаются гипотетическими, поскольку не имеется современных аналогов. Считается, что во время извержений возникали гидротермальные суперплюмы, нагруженные металлами и, скорее всего, аноксидные. Последнее, возможно, вместе с пониженным $\mathrm{pH}$ морской воды обеспечивало подвижность металлов и возможность транспортировки их на большие расстояния [Trabucho-Alexandre et al., 2010; Holmden et al., 2016]. Гидротермальные плюмы распространялись от мест извержения в Тихом, Индийском океанах и в северной полярной области. Данные по изотопам $\mathrm{Nd}$ могут свидетельствовать о проникновении промежуточных водных масс из Тихого океана через Центрально-Американский пролив [MacLeod et al., 2008; Zheng et al., 2013], и с этими водами металлы поступали в СПА и в южную часть Западного Внутреннего бассейна. Предполагается, что Западный Внутренний бассейн, расположенный относительно близко от Карибской провинции, подвергался не только воздействию гидротермальных плюмов, но также и магматической дегазации, что доказывается повышением в разрезе Рок Каньон на интервале ОАЕ2 содержания и летучих, и нелетучих элементов [Snow et al., 2005]. Некоторые исследователи считают, что глобальное распространение продуктов вулканизма в конце сеномана могло происходить не столько в связи с глубоковод- 
ными извержениями, сколько благодаря субаэральным или очень мелководным извержениям [Kuroda et al., 2007]. Роль гидротерм, связанных с вулканизмом COX, дискуссионна. Содержания Оs в современных гидротермальных флюидах СОХ близки к содержаниям в морской воде и не могут изменить ее изотопный состав [Turgeon, Creaser, 2008].

Данные по изотопии осмия вместе с радиоизотопным датированием позволяют оценить продолжительность повышенной активности крупных магматических провинций, совпадающей с событием Бонарелли, в $\sim 600$ тыс. лет (от $\sim 350$ тыс. лет до начала OAE2 до 240 тыс. лет после начала OAE2) [Du Vivier et al., 2015b]. Резкие аномалии металлов в разрезах Западного Внутреннего бассейна США свидетельствуют о том, что магматизм происходил короткими, огромного объема импульсами, длившимися от дней до десятилетий [Snow et al., 2005]. Особенно крупный импульс вулканизма, по данным сопоставления изотопных кривых Оs и С, произошел за 23 тыс. лет перед OAE2 [Turgeon, Creaser, 2008].

Таким образом, наилучшим образом начало события Бонарелли совпадает с началом главного импульса магматизма в Карибской провинции. Однако в это время вулканизм больших объемов происходил по всему земному шару, и точное датирование отдельных крупных его импульсов не всегда возможно, равно как и их корреляция по времени, из-за недостатка данных. Имеется несколько возможностей: 1) главную роль в развитии аноксического события сыграли извержения на Карибском плато, вызвавшие фертилизацию вод Северной Атлантики и океана Тетис, а также расширение зон кислородного минимума в Тихом океане; 2) значителен также вклад других провинций в фертилизацию водной толщи, хотя бы в региональном масштабе; возможно усиление магматизма на планете в позднем сеномане до некоторого порогового значения, вызвавшего нарушение многих геохимических циклов; 3) дополнительным источником биолимитирующих элементов могли быть гидротермальные системы СОХ в периоды резкого увеличения скорости спрединга.

Абсолютные датировки свидетельствуют, что довольно интенсивный вулканизм продолжался на земном шаре и после окончания OAE2. Однако изотопные данные по Оs и другим элементам с относительно небольшим временем пребывания говорят о том, что глобальный вулканизм пошел на спад еще в конце сеномана, что само по себе способствовало завершению события Бонарелли.

\section{ИЗМЕНЕНИЯ КЛИМАТА НА ПРОТЯЖЕНИИ СОБЫТИЯ БОНАРЕЛЛИ}

«Суперплюмовый» эпизод в середине мела стал причиной длительного периода высокого уровня моря и, посредством выделения $\mathrm{CO}_{2}$, высоких палеотемператур [Larson, 1991]. Потепление океанов обедняло их кислородом [Huber et al., 2002] и высвобождало в атмосферу дополнительный $\mathrm{CO}_{2}$, еще более усиливая тепличный эффект [Wignall, 2001]. Жаркий климат способствовал ускорению гидрологического цикла, повышенное $p_{\mathrm{CO}_{2}}$ увеличивало континентальное выветривание; оба фактора способствовали повышенному выносу в океан питательных веществ [Jenkyns, 2010; Pogge von Strandmann et al., 2013].

Тепличному климату середины мела имеется множество палеонтологических и геохимических свидетельств. Например, изотопно-кислородные отношения в карбонатах и фораминиферах и значения $\mathrm{TEX}_{86}$ (индекс тетраэфиров, характеризующий состав мембранных липидов мезофильных архей) из граничных С/Т углеродистых осадков соответствуют высоким температурам поверхности моря (от 25 на высоких широтах до $35-36{ }^{\circ} \mathrm{C}$ на экваторе) [Jenkyns et al., 2004, 2007; Смышляева, 2005; Захаров и др., 2006; Forster et al., 2007]. По изотопно-кислородным данным, воды средней батиали в конце сеномана также резко потеплели от 15 до $20^{\circ} \mathrm{C}$ [Huber et al., 2002]. Уменьшение плотностных градиентов водной толщи облегчило вертикальное поступление питательных веществ, что наряду с другими причинами способствовало увеличению биопродуктивности [Leckie et al., 2002; Hay, 2009]. Температуры поверхности моря упали на $3-4^{\circ} \mathrm{C}$ за 150 тыс. лет, следующих за позитивным сдвигом $\delta^{13} \mathrm{C}$, знаменуя событие похолодания, в Европе именуемое Plenus [Forster et al., 2007; Sinninghe Damsté et al., 2010; Jarvis et al., 2011]. Его связывают с увеличением скорости захоронения $\mathrm{C}_{\text {орг }}$ и соответствующим падением содержания $\mathrm{CO}_{2}$ в атмосфере; причем уменьшение $p_{\mathrm{CO}_{2}}$ подтверждается изменением размера листовых устьиц на ископаемой кутикуле [Barclay et al., 2010]. Затем температуры поверхности моря и содержания $\mathrm{CO}_{2}$ в атмосфере росли вплоть до раннетуронского термального максимума, совпадающего с наиболее высоким уровнем моря в мелу [Kuypers et al., 1999; Huber et al., 2002; Forster et al., 2007; Jarvis et al., 2011].

Потепление в начале OAE2 и по окончании события Plenus согласуются с двумя импульсами вулканизма, устанавливаемыми по повышенным содержаниям металлов в разрезах [Pearce et al., 2009]. Но, если испускание в атмосферу $\mathrm{CO}_{2}$ в течение первого вулканического импульса было скомпенсировано уходом $\mathrm{C}_{\text {орг }}$ в осадки, то в течение второго импульса вулканизма испускание $\mathrm{CO}_{2}$ превысило захоронение углерода, и раннетуронский термальный максимум наступил уже после окончания OAE2 [Jarvis et al., 2011]. Следовательно, климатические изменения не являются главной и достаточной причиной развития и окончания OAЕ2. Бо́льшую роль сыграла эволюция поставки питательных веществ и из- 


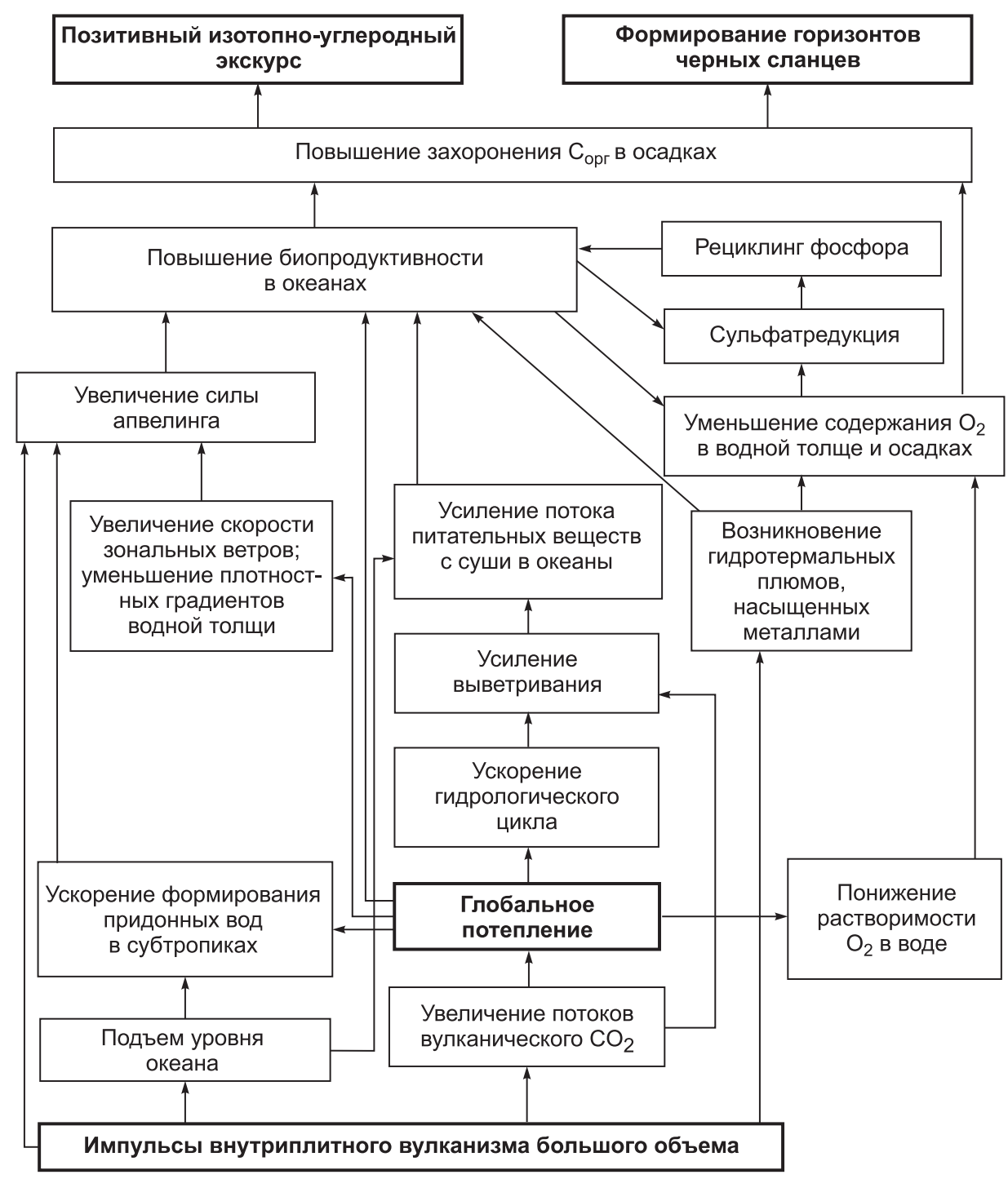

Рис. 4. Схема влияния импульсов вулканизма на формирование горизонтов черных сланцев и изотопно-углеродных экскурсов.

Использованы материалы [Jones, Jenkyns, 2001; Meyer, Kump, 2008; Adams et al., 2010].

менения продуктивности биоты; многие исследователи подчеркивают также важность характера океанской циркуляции.

\section{ВЛИЯНИЕ ОКЕАНСКОЙ ЦИРКУЛЯЦИИ НА РАЗВИТИЕ И ОКОНЧАНИЕ ОАЕ2}

Об океанской циркуляции в прошлом позволяют судить данные по изотопам Nd. Однако, как уже было упомянуто, этих данных накоплено пока недостаточно, чтобы полностью восстановить циркуляцию середины мелового периода. Использование же климатических и биогеохимических моделей дает весьма неоднозначные результаты. Результаты моделирования необходимо сопоставлять с литологическими, геохимическими и палеонтологическими данными, которые довольно бедны для бассейнов Индийского океана и Восточного Тетиса. Поэтому ограничимся сведениями о циркуляции водных масс в Атлантике, Западном Тетисе и Тихом океане.

Большинство моделей предполагает, что Тихий океан середины мела хорошо вентилировался и был богат $\mathrm{O}_{2}$. Движимая ветрами океанская циркуляция в Тихом океане обнаруживает аналоги всех главных современных течений, кроме Антарктического циркумполярного течения [Barron, Peterson, 1990]. Другая модель показывает, что на средних и высоких широтах в середине мела не могли установиться постоянные ветра; сезонные ветра различного направления порождали среднемасштабные вих- 
ри, которые перемешивали воду [Нау, 2009]. Обе модели согласуются с отсутствием аноксидных осадков в глубоких частях Тихого океана и приуроченностью их к вершинам подводных возвышенностей, совпадавшим с локальными зонами кислородного минимума. Развитие этих зон было связано с турбулентным апвеллингом над подводными возвышенностями, а также, возможно, с апвеллингом в экваториальной зоне дивергенции [Sliter, Premoli Silva, 1990; Нay, 2009, 2011]. Важным свидетельством активной циркуляции является то, что граничные $\mathrm{C} / \mathrm{T}$ отложения мало распространены в Тихом океане из-за размыва их интенсивными течениями [Басов, Вишневская, 1991].

Многие модели направлены на объяснение интенсивного накопления ОВ в осадках южной части СПА, которое продолжалось с позднего апта по ранний турон, с максимумом во время OAE2. Одно из предположений состоит в том, что в середине мела СПА была более склонна с истощению $\mathrm{O}_{2}$ из-за ограниченности порогами, сокращающими вентиляцию глубокого океана; кроме того, ее северная граница находилась на $\sim 50^{\circ}$ с.ш. - слишком далеко от полюса, чтобы быть источником глубинных вод [Monteiro et al., 2012]. Глубинные воды формировались в это время на широких арктических шельфах, открытых в Тихий океан, и на юге Пацифики [Hay, 2011; Hasegawa et al., 2013; Donnadieu et al., 2016]; они достигали СПА уже обедненными $\mathrm{O}_{2}$ [Monteiro et al., 2012]. Возрастание $\varepsilon_{\mathrm{Nd}}$ (от -8 до -4) на протяжении середины мела в глубинных водах Атлантического и Индийского океанов связывают с их вялой циркуляцией в этих бассейнах, способствующей накоплению радиогенного $\mathrm{Nd}$, поступающего с вулканической пылью [Robinson et al., 2010]. Начиная с кампана менее радиогенные значения $\varepsilon_{\mathrm{Nd}}$ свидетельствуют о более активной циркуляции и начале формирования глубинных вод на юге Атлантического и Индийского океанов [Robinson et al., 2010; Donnadieu et al., 2016]. Эти изменения циркуляции связывают с похолоданием, расширением Южной Атлантики и углублением пролива, соединяющего Центральную Атлантику с Тихим океаном. Моделирование [Poulsen et al., 2001] показывает, что уже в туроне антарктические придонные воды начали вентилировать атлантические бассейны. Интенсификация циркуляции глубинных вод, вероятно, повлияла на прекращение OAE2 и предотвратила развитие масштабной аноксии в дальнейшем.

В меловом периоде продукция придонных вод происходила также в субтропических мелководных морях в региональном масштабе с интенсивностью, пропорциональной температуре поверхностных вод и скорости их испарения. Эти воды были солеными и теплыми, т. е. небогатыми $\mathrm{O}_{2}$ [Poulsen et al., 2001]. Их роль в возникновении ОАЕ сводилась к поддержанию низкого содержания кислорода в водной толще и к влиянию на силу региональных апвеллингов, выносящих на поверхность питательные вещества.

Существуют модели, в соответствии с которыми интенсивность глобальной термогалинной циркуляции в середине мела была сходной или немного более высокой, чем в настоящее время [TrabuchoAlexandre et al., 2010]. В особенности это может касаться увеличенной скорости зональных ветров и интенсификации связанных с ними апвеллингов [Jones, Jenkyns, 2001]. Достаточную интенсивность термогалинной циркуляции предполагает модель [Trabucho-Alexandre et al., 2010], в соответствии с которой СПА середины мела являлась ловушкой для питательных веществ, что было обусловлено палеогеографией и системами ветров. Длинная ось этого бассейна была параллельна направлению пассатов, которые создавали течение поверхностных вод в Тихий океан. Кроме того, имел место приток в СПА подповерхностных вод с запада на восток. Промежуточные воды транспортировали из Пацифики питательные вещества, связанные с подводными магматическими событиями. Далее питательные вещества поднимались в эвфотическую зону посредством движимого пассатами апвеллинга вдоль южных окраин Северо-Атлантического бассейна, что и сделало эту область фокусом отложения черных сланцев. Тетической области и севера Атлантики достигало меньшее количество питательных веществ, в связи с чем накопление обогащенных $\mathrm{C}_{\text {орг }}$ осадков здесь происходило в меньших масштабах, в основном в позднем сеномане. С данной моделью согласуется пространственное распределение элементных аномалий на C/T границе [Orth et al., 1993]. Высокий уровень моря облегчал прохождение подповерхностных вод через пролив и предотвращал разбавление обогащенных ОВ осадков терригенным материалом. Прекращение формирования богатых органикой фаций в раннем туроне связано с открытием экваториальной Атлантики для глубинных вод и новым характером циркуляции, при котором на всех глубинах водные массы двигались на запад, в Тихий океан [Trabucho-Alexandre et al., 2010; Donnadieu et al., 2016].

Таким образом, палеогеография оказывала заметное влияние на циркуляцию водных масс и снабжение океанов кислородом, а также на распределение в них питательных веществ, создавая предпосылки для возникновения и прекращения аноксии.

\section{ИЗМЕНЕНИЯ ПЕРВИЧНОЙ ПРОДУКТИВНОСТИ ВО ВРЕМЯ ОАЕ2}

Моделирование показывает, что биопродуктивность является наиболее важным фактором, который наряду с палеогеографией влияет на степень истощения кислорода в океане [Monteiro et al., 2012]. 
Событие Бонарелли характеризуется высокой первичной продуктивностью в поверхностных водах и сменой планктонных сообществ. В европейских разрезах на интервалах OAE2 зафиксировано резкое уменьшение концентрации $\mathrm{CaCO}_{3}$ [Schlanger et al., 1987; Kuroda et al., 2005; Turgeon, Brumsack, 2006], вызванное кризисом карбонатного планктона. Причиной этого явления могло стать подкисление океанов вследствие выделения $\mathrm{CO}_{2}$ при магматической деятельности [Erba, Bottini, 2009], а также эвтрофикация океанов, которая вызвала увеличение массы органикостенного планктона за счет известкового. В пелагических черных сланцах СПА в скважинах 144, 367 и 603B DSDP на интервале OAE2 отмечены высокие содержания 2-метилгопаноидов - мембранных липидов, характерных для цианобактерий. Изотопный состав азота $\left(\delta^{15} \mathrm{~N}\right)$ этих отложений свидетельствует о процессе азотфиксации, имевшем место во время их формирования. Это означает, что азотфиксирующие цианобактерии являлись важными продуцентами ОВ углеродистых осадков, накапливавшихся в течение события Бонарелли [Kuypers et al., 2004b]. Цианобактерии получали преимущество перед водорослями в условиях нитратредукции, дающей начало процессам денитрификации и анаммокса, в конечном итоге приводящим к уходу азота в атмосферу и недоступности его для большинства организмов [Jenkyns et al., 2007].

Для поддержания высокой первичной продуктивности во время ОАЕ требовалась повышенная поставка в океаны биологически значимых элементов (N, P, Fe и др.). Предложены следующие механизмы такой поставки (рис. 4): 1) гидротермальная активность [Sinton, Duncan, 1997; Snow et al., 2005; MacLeod et al., 2008]; 2) увеличенная поставка питательных веществ реками в обстановке теплого климата с интенсифицированным гидрологическим циклом и повышенным выветриванием [Pogge von Strandmann et al., 2013]; 3) выщелачивание питательных веществ из затопленных при трансгрессии областей шельфа [Гаврилов и др., 2002; Mort et al., 2008]; 4) увеличенное поступление фосфора из осадков из-за восстановления оксигидроксидов Fe, связывавших фосфаты, и ограничение образования аутигенных Са-Р минералов в дизоксидных/аноксидных условиях [Van Cappellen, Ingall, 1994; Kraal et al., 2010; Poulton et al., 2015]; 5) фиксация азота цианобактериями, позволявшая им поддерживать как свою собственную продуктивность, так и продуктивность организмов более высоких трофических уровней [Kuypers et al., 2004b]. Для поступления биолимитирующих элементов в фотическую зону конкретного района мог быть необходим достаточно сильный апвеллинг промежуточных и глубинных вод [Poulsen et al., 2001; Trabucho-Alexandre et al., 2010]. Перечисленные механизмы в конкретных регионах и в течение конкретных ОАЕ могли действовать по отдельности или в различных сочетаниях.

Позитивный изотопно-углеродный экскурс, связанный с ОАЕ2, несмотря на свое глобальное проявление, был вызван главным образом захоронением $\mathrm{C}_{\text {орг }}$, происходившим в так называемых эвксинных горячих точках [Owens et al., 2013]. Как уже было показано, главным районом отложения ОВ являлась южная часть СПА. Например, подсчитано, что $\sim 2 \%$ глобального избытка захоронения $\mathrm{C}_{\text {орг }}$, связанного с OAE2, было отложено в одном только бассейне Тарфайя, на площади, которая составляла 0.05 \% глобального C/T океанского дна [Kolonic et al., 2005]. В подобных бассейнах исчерпание запасов Мо в морской воде могло затруднить фиксацию азота цианобактериями, поскольку для азотфиксации необходима нитрогеназа - комплекс ферментов, в состав которых входит Mo [Owens et al., 2016]. Это приводило к постепенному снижению продуктивности.

Изменение скорости аккумуляции фосфора (мг/см²/тыс. лет), водородного индекса НІ и отношения $\mathrm{C} / \mathrm{P}$ на протяжении разрезов позволяют реконструировать эволюцию события Бонарелли. Скорости аккумуляции Р растут в начале OAE2, затем снижаются до конца этого события, после чего возрастают. Такая закономерность выявлена в разрезах возвышенности Демерара, бассейна Тарфайя, Центральной Италии, Южной Испании, Южной Англии, Западного Внутреннего бассейна Северной Америки, Тибета [Mort et al., 2007b, 2008; Kraal et al., 2010; Bomou et al., 2013]. Увеличенные содержания и скорость аккумуляции Р в начале OAE2 (перед самым экскурсом $\delta^{13} \mathrm{C}$ и в его начале) отражает повышенную продуктивность (возможные причины ее повышения изложены выше - пункты 1, 2, 3). Сохранность ОВ в это время была низкой (низкие НI), и его окисление высвобождало фосфор, который формировал аутигенные минералы. В течение главной стадии ОАЕ2 фосфор уходил из осадков, создавая в них высокие отношения $\mathrm{C} / \mathrm{P}$, вновь включался в круговорот и поддерживал высокую продуктивность. На поздних стадиях ОАЕ2 продуктивность стала падать, и ведущую роль в накоплении $\mathrm{C}_{\text {орг }}$ играло его сохранение в условиях дефицита кислорода [Mort et al., 2007a]. После окончания OAE2 эффективность захоронения фосфора повысилась, а $\mathrm{C}_{\text {орг }}$ понизилась, вследствие чего уменьшились отношения $\mathrm{C} / \mathrm{P}$ в осадках.

Повышенная продуктивность в течение события Бонарелли вела: 1) к изоляции углерода в осадках; 2) к увеличению содержания $\mathrm{O}_{2}$ путем фотосинтеза в атмосфере и океанах, что повлекло за собой удаление фосфора в осадки, а также более эффективное окисление ОВ [Kuypers et al., 2004b; Mort et al., 2007a]; 3) к широкому развитию процесса сульфатредукции, который уменьшил океанский резервуар $\mathrm{SO}_{4}^{2-}$, что также увеличило поток $\mathrm{O}_{2}$ в атмосферу [Ohkouchi et al., 1999]; кроме того, и сама сульфатредукция в результате сократилась, и фосфор вновь смог связываться в оксигидроксидах Fe [Adams et al., $2010]$; 4) к переходу в осадки биологически значимых элементов, истощение которых в водной толще 
ограничило продуктивность [Owens et al., 2013, 2016]. Все эти процессы наряду с изменениями океанской циркуляции и возможным ослаблением вулканизма вели к окончанию OАЕ2 и возвращению океана к более кислородным условиям.

\section{ЗАКЛЮЧЕНИЕ}

Событие Бонарелли является наиболее значительным аноксическим событием мелового периода, длившимся около 600 тыс. лет. Анализ его следов в осадочных разрезах позволяет понять многочисленные осадочные, биотические и геохимические процессы, происходившие вблизи границы сеномана и турона, и их взаимосвязь. Отложение черных сланцев в это время является следствием благоприятствующей палеогеографии и океанской циркуляции, а также поступления в океаны питательных веществ. Событие Бонарелли имеет глобальное проявление, хотя отложение обогащенных органикой осадков не было вполне синхронным, и они распространены на земном шаре крайне неравномерно. Фокусом отложения черных сланцев являлась Северная прото-Атлантика, в то время как в Тихом океане углеродистые породы формировались в значительно меньшем масштабе и лишь в приэкваториальной части.

Распределение в разрезах аномалий металлов и кривые отношений стабильных изотопов различных элементов указывают на усиление вулканической и гидротермальной деятельности в конце сеномана, в том числе на два крупных магматических импульса - непосредственно перед OAE2 и в начале плато $\delta^{13} \mathrm{C}$. С этими импульсами согласуются эпизоды увеличения концентрации $\mathrm{CO}_{2}$ в атмосфере и повышения температуры, установленные по независимым данным. Некоторые изотопные сдвиги могут указывать на увеличение континентального выветривания в начале OAE2, которое, возможно, связано с выделением $\mathrm{CO}_{2}$ в атмосферу при интенсивном вулканизме и с потеплением.

Имеются радиоизотопные датировки вулканических пород различных крупных магматических провинций, близкие ко времени проявления события Бонарелли. Непосредственно предшествует OAE2 начало главного импульса платобазальтового магматизма в Карибской провинции. Также установлено, что вулканизм происходил в конце сеномана в Арктической провинции, на плато Кергелен, хр. Брокен, плато Онтонг-Джава, на подводных горах западной части Тихого океана.

Возрастание интенсивности вулканизма запустило ряд процессов, приведших к увеличению доступности питательных веществ, которое стимулировало первичную продуктивность поверхностных вод океанов. Это привело к расходованию кислорода на разложение ОВ и экспансии аноксидных и эвксинных обстановок. На главной стадии ОАЕ2 продуктивность поддерживалась также рециклингом фосфора из дизоксидных/аноксидных осадков. Взаимосвязь основных процессов и механизмов, вызывающих и поддерживающих ОАЕ, показана на рис. 4. Чтобы данная схема работала, необходим тепличный климат с пониженной стратификацией океанской водной толщи. В случае ОАЕ2 большую роль играло также существование узкого океанского бассейна (раскрывающейся Атлантики) с ограниченной циркуляцией глубинных вод, в пределах которого могли формироваться ловушки для питательных веществ.

Ряд геохимических и биохимических процессов, связанных с повышенной продуктивностью, в конечном счете, вел к ее снижению. Это является замечательной иллюстрацией того, как биосфера может восстанавливать среду в глобальном масштабе, преодолевая возмущения геохимических циклов. В течение события Бонарелли привнесенные в океан токсичные и значимые для биоты элементы были удалены в осадки, и понижение продуктивности способствовало возвращению океана к кислородным условиям. При этом $p_{\mathrm{CO}_{2}}$ в атмосфере в конце ОАЕ2 оставалось высоким, как и температура, что, повидимому, свидетельствует о дальнейшем поступлении вулканического $\mathrm{CO}_{2}$. После снижения интенсивности вулканизма диоксид углерода удалялся из атмосферы в углеродистые осадки, которые еще некоторое время после окончания OAE2 накапливались на юге Северной прото-Атлантики, и в карбонаты, отлагавшиеся в эпиконтинентальных морях. Окончанию OAE2, по-видимому, также способствовало увеличение циркуляции глубинных вод в Атлантике.

Работа выполнена при поддержке РФФИ (грант 16-05-00546).

\section{ЛИТЕРАТУРА}

Басов И.А., Вишневская В.С. Стратиграфия верхнего мезозоя Тихого океана. М., Наука, 1991, $200 \mathrm{c}$.

Вишневская В.С. Радиоляриевая биостратиграфия юры и мела России. М., ГЕОС, 2001, 376 с.

Гаврилов Ю.О., Щепетова Е.В., Барабошкин Е.Ю., Щербинина Е.А. Аноксический раннемеловой бассейн Русской плиты: седиментология и геохимия // Литология и полезные ископаемые, 2002, № 4, с. 359-380.

Гаврилов Ю.О., Щербинина Е.А., Голованова О.В., Покровский Б.Г. Позднесеноманское палеоэкологическое событие OAE2 в Восточно-Кавказском бассейне Северного Перитетиса // Литология и полезные ископаемые, 2013, № 6, с. 522-551. 
Захаров Ю.Д., Смышляева О.П., Попов А.М., Шигэта Я. Изотопный состав позднемезозойских органогенных карбонатов Дальнего Востока. Владивосток, Дальнаука, 2006, 199 с.

Лебедева Н.К., Зверев К.В. Седиментологический и палинологический анализ сеноман-туронского события на севере Сибири // Геология и геофизика, 2003, т. 44 (8), с. $769-780$.

Левитан М.А., Алексеев А.С., Бадулина Н.В., Гирин Ю.П., Копаевич Л.Ф., Кубракова И.В., Тютюнник О.А., Чудецкий М.Ю. Геохимия пограничных сеноман-туронских отложений Горного Крыма и Северо-Западного Кавказа // Геохимия, 2010, № 6, с. 570-591.

Найдин Д.П. Позднемеловые события на востоке Европейской палеобиогеографической области. Статья 2. События рубежей сеноман/турон и маастрихт/даний // Бюл. МОИП, Отд. геол., 1993, т. 68, вып. 3, с. 33-53.

Савельев Д.П. Меловые внутриплитные вулканиты Восточной Камчатки: геологическая позиция и влияние на островодужный вулканизм // Геология и разведка, 2004, № 2, с. 16-19.

Савельев Д.П., Ландер А.В., Пронина Н.В., Савельева О.Л. Первая находка углистых пород в меловых палеоокеанических комплексах Восточной Камчатки // Вестник КРАУНЦ. Серия Науки о Земле, 2007, № 2 (10), с. 102-104.

Савельева О.Л. Ритмичность осадконакопления и следы аноксических событий в меловых (альбсеноманских) отложениях Восточной Камчатки: Автореф. дис. ... к. г.-м. н. М., 2009, 25 с.

Седов А.П., Матвеенков В.В., Волокитина Л.П., Рашидов В.А., Казакевич В.И., Лукьянов С.В. Качественная модель формирования цепей подводных гор // Вестник КРАУНЦ. Серия Науки о Земле, 2005, № 5, с. 24-44.

Смышляева О.П. Изотопный состав меловых органогенных карбонатов Дальнего Востока (Пенжинская губа, Крильон, Хоккайдо) и глобальная корреляция позднемезозойских событий по изотопным данным: Автореф. дис. ... к.г.-м.н. Владивосток, 2005, 28 с.

Adams D.D., Hurtgen M.T., Sageman B.B. Volcanic triggering of a biogeochemical cascade during Oceanic Anoxic Event 2 // Nat. Geosci., 2010, v. 3, p. 201-204.

Ando A., Nakano T., Kaiho K., Kobayashi T., Kokado E., Khim B.-K. Onset of seawater ${ }^{87} \mathrm{Sr} /{ }^{86} \mathrm{Sr}$ excursion prior to Cenomanian-Turonian Oceanic Anoxic Event 2? New Late Cretaceous strontium isotope curve from the central Pacific Ocean // J. Foraminiferal Res., 2009, v. 39, № 4, p. 322-334.

Arthur M.A., Dean W.E., Pratt L.M. Geochemical and climatic effects of increased marine organic carbon burial at the Cenomanian/Turonian boundary // Nature, 1988, v. 335, p. 714-717.

Barclay R.S., McElwain J.C., Sageman B.B. Volcanic $\mathrm{CO}_{2}$ pulse activates carbon sequestration during Cretaceous Oceanic Anoxic Event $2 / /$ Nat. Geosci., 2010, v. 3, p. 205-208.

Barron E.J., Peterson W.H. Mid-Cretaceous ocean circulation: results from model sensitivity studies // Paleoceanography, 1990, v. 5, № 3, p. 319-337.

Blättler C.L., Jenkyns H.C., Reynard L.M., Henderson G.M. Significant increases in global weathering during Oceanic Anoxic Events 1a and 2 indicated by calcium isotopes // Earth Planet. Sci. Lett., 2011, v. 309, p. $77-88$.

Bomou B., Adatte T., Tantawy A.A., Mort H., Fleitmann D., Huang Y., Föllmi K.B. The expression of the Cenomanian-Turonian oceanic anoxic event in Tibet // Palaeogeogr. Palaeoclimatol. Palaeoecol., 2013, v. 369 , p. $466-481$.

Bralower T.J. Volcanic cause of catastrophe // Nature, 2008, v. 454 (7202), p. 285-287.

Bralower T.J., Fullagar P.D., Paull C.K., Dwyer G.S., Leckie R.M. Mid-Cretaceous strontium-isotope stratigraphy of deep-sea sections // Geol. Soc. Amer. Bull., 1997, v. 109, p. 1421-1442.

Broecker W., Peng T. Tracers in the sea. Eldigio Press, Lamont-Doherty Geological Observatory, Palisades, New York, 1982, 690 p.

Coccioni R., Galeotti S. The mid-Cenomanian event: prelude to OAE2 // Palaeogeogr. Palaeoclimatol., Palaeoecol., 2003, v. 190, p. 427-440.

Dean W.E., Claypool G.E., Thiede J. Origin of organic-carbon-rich mid-Cretaceous limestones, MidPacific Mountains and Southern Hess Rise // Initial reports of the Deep Sea Drilling Project. Washington, 1981, v. 62 , p. $877-890$.

Dickson A.J., Jenkyns H.C., Porcelli D., van den Boorn S., Idiz E. Basin-scale controls on the molybdenum-isotope composition of seawater during Oceanic Anoxic Event 2 (Late Cretaceous) // Geochim. Cosmochim. Acta, 2016, v. 178, p. 291-306.

Donnadieu Y., Pucéat E., Moiroud M., Guillocheau F., Deconinck J.-F. A better-ventilated ocean triggered by Late Cretaceous changes in continental configuration // Nat. Commun., 2016, v. 7, 10316, doi:10.1038/ ncomms10316.

Du Vivier A.D.C., Selby D., Sageman B.B., Jarvis I., Gröcke D.R., Voigt S. Marine ${ }^{187} \mathrm{Os} / 188 \mathrm{Os}$ isotope stratigraphy reveals the interaction of volcanism and ocean circulation during Oceanic Anoxic Event 2 // Earth Planet. Sci. Lett., 2014, v. 389, p. 23-33. 
Du Vivier A.D.C., Jacobson A.D., Lehn G.O., Selby D., Hurtgen M.T., Sageman B.B. Ca isotope stratigraphy across the Cenomanian-Turonian OAE2: Links between volcanism, seawater geochemistry, and the carbonate fractionation factor // Earth Planet. Sci. Lett., 2015a, v. 416, p. 121-131.

Du Vivier A.D.C., Selby D., Condon D.J., Takashima R., Nishi H. Pacific ${ }^{187} \mathrm{Os} /{ }^{188} \mathrm{Os}$ isotope chemistry and U-Pb geochronology: Synchroneity of global Os isotope change across OAE2 // Earth Planet. Sci. Lett., 2015b, v. 428, p. 204-216.

Eldrett J.S., Minisini D., Bergman S.C. Decoupling of the carbon cycle during ocean anoxic event 2 // Geology, 2014, v. 42, p. 567-570.

El-Sabbagh A., Tantawy A.A., Keller G., Khozyem H., Spangenberg J., Adatte T., Gertsch B. Stratigraphy of the Cenomanian-Turonian Oceanic Anoxic Event OAE2 in shallow shelf sequences of NE Egypt // Cretaceous Res., 2011, v. 32, p. 705-722.

Erba E., Bottini C. The response of Cretaceous calcareous nannoplankton to $p \mathrm{CO}_{2}$ and ocean acidification // Geochim. Cosmochim. Acta, 2009, v. 73, № 13S, p. A334.

Forster A., Schouten S., Moriya K., Wilson P.A., Sinninghe Damsté J.S. Tropical warming and intermittent cooling during the Cenomanian/Turonian oceanic anoxic event 2: Sea surface temperature records from the equatorial Atlantic // Paleoceanography, 2007, v. 22, PA1219.

Forster A., Kuypers M.M.M., Turgeon S.C., Brumsack H.-J., Petrizzo M.R., Sinninghe Damsté J.S. The Cenomanian/Turonian oceanic anoxic event in the South Atlantic: New insights from a geochemical study of DSDP Site 530A // Palaeogeogr. Palaeoclimatol. Palaeoecol., 2008, v. 267, p. 256-283.

Frey F.A., Coffin M.F., Wallace P.J., Weis D. Leg 183 synthesis: Kerguelen Plateau-Broken Ridge-a large igneous province // Proceedings of the Ocean Drilling Program, Scientific results, v. 183, College Station, Texas, 2003, p. 1-48.

Frijia G., Parente M. Strontium isotope stratigraphy in the upper Cenomanian shallow-water carbonates of the southern Apennines: Short-term perturbations of marine ${ }^{87} \mathrm{Sr} /{ }^{86} \mathrm{Sr}$ during the oceanic anoxic event 2 // Palaeogeogr. Palaeoclimatol. Palaeoecol., 2008, v. 261, p. 15-29.

Hasegawa T. Cretaceous terrestrial paleoenvironments of northeastern Asia suggested from carbon isotope stratigraphy: Increased atmospheric $p \mathrm{CO}_{2}$-induced climate // J. Asian Earth Sci., 2003, v. 21, p. 849-859.

Hasegawa T., Crampton J.S., Schiøler P., Field B., Fukushi K., Kakizaki Y. Carbon isotope stratigraphy and depositional oxia through Cenomanian/Turonian boundary sequences (Upper Cretaceous) in New Zealand // Cretaceous Res., 2013, v. 40, p. 61-80.

Hauff F., Hoernle K., van den Bogaard P., Alvarado G.E., Garbe-Schonberg C.D. Age and geochemistry of basaltic complexes in western Costa Rica: Contributions to the geotectonic evolution of Central America // Geochem. Geophys. Geosyst., 2000, v. 1, 1999GC000020.

Hay W.W. Cretaceous oceans and ocean modelling // Cretaceous oceanic red beds: stratigraphy, composition, origins and paleoceanographic and paleoclimatic significance. SEPM Special Publication, 2009, № 91, p. $243-271$.

Hay W.W. Can humans force a return to a 'Cretaceous' climate? // Sediment. Geol., 2011, v. 235, p. 5-26.

Herrle J.O., Schröder-Adams C.J., Davis W., Pugh A.T., Galloway J.M., Fath J. Mid-Cretaceous High Arctic stratigraphy, climate, and Oceanic Anoxic Events // Geology, 2015, v. 43, № 5, p. 403-406.

Hetzel A., Böttcher M.E., Wortmann U.G., Brumsack H. Paleo-redox conditions during OAE2 reflected in Demerara Rise sediment geochemistry (ODP Leg 207) // Palaeogeogr. Palaeoclimatol. Palaeoecol., 2009 , v. 273, p. 302-328.

Hoernle K., Hauff F., van den Bogaard P. 70 m.y. history (139-69 Ma) for the Caribbean large igneous province // Geology, 2004, v. 32, № 8, p. 697-700.

Holbourn A., Kuhnt W. Cenomanian-Turonian palaeoceanographic change on the Kerguelen Plateau: A comparison with Northern Hemisphere records // Cretaceous Res., 2002, v. 23, p. 333-349.

Holmden C., Jacobson A.D., Sageman B.B., Hurtgen M.T. Response of the Cr isotope proxy to Cretaceous Ocean Anoxic Event 2 in a pelagic carbonate succession from the Western Interior Seaway // Geochim. Cosmochim. Acta, 2016, v. 186, p. 277-295.

Huber B.T., Norris R.D., MacLeod K.G. Deep-sea paleotemperature record of extreme warmth during the Cretaceous // Geology, 2002, v. 30, № 2, p. 123-126.

Jarvis I., Gale A.S., Jenkyns H.C., Pearce M.A. Secular variation in Late Cretaceous carbon isotopes: A new $\delta^{13} \mathrm{C}$ carbonate reference curve for the Cenomanian-Campanian (99.6-70.6 Ma) // Geol. Mag., 2006, v. 143 , p. $561-608$.

Jarvis I., Lignum J.S., Gröcke D.R., Jenkyns H.C., Pearce M.A. Black shale deposition, atmospheric $\mathrm{CO}_{2}$ drawdown, and cooling during the Cenomanian-Turonian Ocean Anoxic Event // Paleoceanography, 2011, v. 26, PA3201. 
Jenkyns H.C. Geochemistry of oceanic anoxic events // Geochem. Geophys. Geosyst., 2010, v. 11, № 3, Q03004.

Jenkyns H.C., Gale A.S., Corfield R.M. Carbon- and oxygen-isotope stratigraphy of the English Chalk and Italian Scaglia and its palaeoclimatic significance // Geol. Mag., 1994, v. 131, p. 1-34.

Jenkyns H.C., Mutterlose J., Sliter W.V. Upper Cretaceous carbon- and oxygen-isotope stratigraphy of deep-water sediments from the North-Central Pacific (Site 869, flank of Pikinni-Wodejebato, Marshall Islands) // Proceedings of the Ocean Drilling Program, Scientific results, v. 143, College Station, Texas, 1995, p. $105-110$.

Jenkyns H.C., Forster A., Schouten S., Sinninghe Damsté J.S. High temperatures in the Late Cretaceous Arctic Ocean // Nature, 2004, v. 432, p. 888-892.

Jenkyns H.C., Matthews A., Tsikos H., Erel Y. Nitrate reduction, sulfate reduction, and sedimentary iron isotope evolution during the Cenomanian-Turonian oceanic anoxic event // Paleoceanography, 2007, v. 22, PA3208.

Jones C.E., Jenkyns H.C. Seawater strontium isotopes, oceanic anoxic events, and seafloor hydrothermal activity in the Jurassic and Cretaceous // Amer. J. Sci., 2001, v. 301, p. 112-149.

Karakitsios V., Tsikos H., van Breugel Y., Koletti L., Sinninghe Damsté J.S., Jenkyns H.C. First evidence for the Cenomanian-Turonian oceanic anoxic event (OAE2, 'Bonarelli' event) from the Ionian Zone, western continental Greece // Int. J. Earth Sci., 2007, v. 96, № 2, p. 343-352.

Kolonic S., Wagner T., Forster A., Sinninghe Damsté J.S., Walsworth-Bell B., Erba E., Turgeon S., Brumsack H.-J., Chellai E.H., Tsikos H., Kuhnt W., Kuypers M.M.M. Black shale deposition on the northwest African Shelf during the Cenomanian/Turonian oceanic anoxic event: Climate coupling and global organic carbon burial // Paleoceanography, 2005, v. 20, p. 95-128.

Kraal P., Slomp C.P., Forster A., Kuypers M.M.M. Phosphorus cycling from the margin to abyssal depths in the proto-Atlantic during oceanic anoxic event 2 // Palaeogeogr. Palaeoclimatol. Palaeoecol., 2010, v. 295 , p. $42-54$.

Kuroda J., Ohkouchi N. Implication of spatiotemporal distribution of black shales deposited during the Cretaceous Oceanic Anoxic Event-2 // Paleontol. Res., 2006, v. 10, № 4, p. 345-358.

Kuroda J., Ohkouchi N., Ishii T., Tokuyama H., Taira A. Laminascale analysis of sedimentary components in Cretaceous black shales: Paleoceanographic implications for oceanic anoxic events // Geochim. Cosmochim. Acta, 2005, v. 69, p. 1479-1494.

Kuroda J., Ogawa N.O., Tanimizu M., Coffin M.F., Tokuyama H., Kitazato H., Ohkouchi N. Contemporaneous massive subaerial volcanism and Late Cretaceous Oceanic Anoxic Event $2 / /$ Earth Planet. Sci. Lett., 2007, v. 256, p. 211-223.

Kuypers M.M.M., Pancost R.D., Sinninghe Damsté J.S. A large and abrupt fall in atmospheric $\mathrm{CO}_{2}$ concentration during Cretaceous times // Nature, 1999, v. 399, p. 342-345.

Kuypers M.M.M., Pancost R.D., Nijenhuis I.A., Sinninghe Damsté J.S. Enhanced productivity led to increased organic carbon burial in the euxinic North Atlantic basin during the late Cenomanian oceanic anoxic event // Paleoceanography, 2002, v. 17, № 4, PA1051, doi:10.1029/2000PA000569.

Kuypers M.M.M., Lourens L.J., Rijpstra W.I.C, Pancost R.D., Nijenhuis I.A., Sinninghe Damsté J.S. Orbital forcing of organic carbon burial in the proto-North Atlantic during oceanic anoxic event 2 // Earth Planet. Sci. Lett., 2004a, v. 228, p. 465-482.

Kuypers M.M.M., van Breugel Y., Schouten S., Erba E., Sinninghe Damsté J.S. N 2 -fixing cyanobacteria supplied nutrient N for Cretaceous oceanic anoxic events // Geology, 2004b, v. 32, № 10, p. 853-856.

Larson R.L. Geological consequences of superplumes // Geology, 1991, v. 19, p. 963-966.

Leckie R.M., Bralower T.J., Cashman R. Oceanic anoxic events and plankton evolution: Biotic response to tectonic forcing during the mid-Cretaceous // Paleoceanography, 2002, v. 17, № 3, p. 13-1-13-29, doi: 10.1029/2001PA000623.

Lenniger M., Nøhr-Hansen H., Hills L.V., Bjerrum C.J. Arctic black shale formation during Cretaceous Oceanic Anoxic Event 2 // Geology, 2014, v. 42, № 9, p. 799-802.

Li G., Jiang G., Hu X., Wan X. New biostratigraphic data from the Cretaceous Bolinxiala Formation in Zanda, southwestern Tibet of China, and their paleogeographic and paleoceanographic implications // Cretaceous Res., 2009, v. 30, p. 1005-1018.

Luciani V., Cobianchi M. The Bonarelli Level and other black shales in the Cenomanian-Turonian of the northeastern Dolomites (Italy): Calcareous nannofossil and foraminiferal data // Cretaceous Res., 1999, v. 20, p. $135-167$.

MacLeod K.G., Martin E.E., Blair S.W. Nd isotopic excursion across Cretaceous ocean anoxic event 2 (Cenomanian-Turonian) in the tropical North Atlantic // Geology, 2008, v. 36, p. 811-814. 
Magtoto C.Y., Fernando A.G.S., Takashima R., Nishi H., Tomosugi T. Calcareous nannofossil biostratigraphy of the Cenomanian-Turonian Oceanic Anoxic Event 2 (OAE2) record in California, USA // The Second International symposium of International Geoscience Programme (IGCP) Project 608 «Cretaceous ecosystems and their responses to paleoenvironmental changes in Asia and the Western Pacific», Abstract volume, Tokyo, 2014, p. 32.

Mahoney J.J., Storey M., Duncan R.A., Spencer K.J., Pringle M. Geochemistry and geochronology of Leg 130 basement lavas: nature and origin of the Ontong Java plateau // Proceedings of the Ocean Drilling Program, Scientific results, v. 130, College Station, Texas, 1993, p. 3-22.

Mahoney J.J., Fitton J.G., Wallace P.J., Antretter M.J., Banerjee N.R., Bergen J.A., Cairns G., Castillo P.R., Chambers L.M., Chazey III W.J., Coffin M.F., Godard M.M., Hall S.A., Honnorez J., Ingle S.P., Kroenke L.W., MacLeod K.G., Naruse H., Neal C.R., Ogg J.G., Riisager P., Sano T., Sikora P.J., van der Werff W., White R.V., Zhao X. Leg 192 summary // Proceedings of the Ocean Drilling Program, Initial reports, v. 192, College Station, Texas, 2001, p. 1-75.

Martin E.E., MacLeod K.G., Jimenez Berrocso A., Bourbon E. Water mass circulation on Demerara Rise during the Late Cretaceous based on Nd isotopes // Earth Planet. Sci. Lett., 2012, v. 327-328, p. 111-120.

McArthur J.M., Howarth R.J., Shields G.A. Strontium isotope stratigraphy // The Geologic Time Scale. Amsterdam, Elsevier, 2012, p. 127-144.

Meyer K.M., Kump L.R. Oceanic euxinia in Earth history: causes and consequences // The Ann. Rev. Earth Planet. Sci., 2008, v. 36, p. 251-288.

Meyers S.R., Siewert S.E., Singer B.S., Sageman B.B., Condon D.J., Obradovich J.D., Jicha B.R., Sawyer D.A. Intercalibration of radioisotopic and astrochronologic time scales for the Cenomanian-Turonian boundary interval, Western Interior Basin, USA // Geology, 2012, v. 40, p. 7-10.

Moiroud M., Pucéat E., Donnadieu Y., Bayon G., Moriya K., Deconinck J.-F., Boyet M. Evolution of the neodymium isotopic signature of neritic seawater on a northwestern Pacific margin: new constrains on possible end-members for the composition of deep-water masses in the Late Cretaceous ocean // Chem. Geol., 2013, v. 356, p. $160-170$.

Monteiro F.M., Pancost R.D., Ridgwell A., Donnadieu Y. Nutrients as the dominant control on the spread of anoxia and euxinia across the Cenomanian-Turonian oceanic anoxic event (OAE2): Model-data comparison // Paleoceanography, 2012, v. 27, PA4209.

Montoya-Pino C., Weyer S., Anbar A.D., Pross J., Oschmann W., van de Schootbrugge B., Arz H.W. Global enhancement of ocean anoxia during Oceanic Anoxic Event 2: a quantitative approach using U isotopes // Geology, 2010, v. 38, p. 315-318.

Mort H.P., Adatte T., Föllmi K.B., Keller G., Steinmann P., Matera V., Berner Z., Stüben D. Phosphorus and the roles of productivity and nutrient recycling during oceanic anoxic event 2 // Geology, 2007a, v. 35, № 6, p. 483-486.

Mort H., Jacquat O., Adatte T., Steinmann P., Föllmi K.B., Matera V., Berner Z., Stüben D. The Cenomanian/Turonian anoxic event at the Bonarelli Level in Italy and Spain: enhanced productivity and/or better preservation? // Cretaceous Res., 2007b, v. 28, p. 597-612.

Mort H.P., Adatte T., Keller G., Bartels D., Föllmi K.B., Steinmann P., Berner Z., Chellai E.H. Organic carbon deposition and phosphorus accumulation during Oceanic Anoxic Event 2 in Tarfaya, Morocco // Cretaceous Res., 2008, v. 29, p. 1008-1023.

Nakanishi M., Nakamura Y., Coffin M.F., Hoernle K., Werner R. Topographic expression of the Danger Islands Troughs and implications for the tectonic evolution of the Manihiki Plateau, western equatorial Pacific Ocean // The origin, evolution, and environmental evolution of oceanic large igneous provinces // Geol. Soc. Amer. Spec. Pap., 2015, № 511, p. 195-220.

Navarro-Ramirez J.P., Bodin S., Immenhauser A. Ongoing Cenomanian-Turonian heterozoan carbonate production in the neritic settings of Peru // Sediment. Geol., 2016, v. 331, p. 78-93.

Nemoto T., Hasegawa T. Submillennial resolution carbon isotope stratigraphy across the Oceanic Anoxic Event 2 horizon in the Tappu section, Hokkaido, Japan // Palaeogeogr. Palaeoclimatol. Palaeoecol., 2011, v. 309 , p. $271-280$.

Núñez-Useche F., Canet C., Barragán R., Alfonso P. Bioevents and redox conditions around the Cenomanian-Turonian anoxic event in Central Mexico // Palaeogeogr. Palaeoclimatol. Palaeoecol., 2016, v. 449, p. $205-226$.

Ohkouchi N., Kawamura K., Kajiwara Y., Wada E., Okada M., Kanamatsu T., Taira A. Sulfur isotope records around Livello Bonarelli (northern Apennines, Italy) black shale at the Cenomanian-Turonian boundary // Geology, 1999, v. 27, p. 535-538.

Orth C.J., Attrep M., Quintana L.R., Elder W.P., Kauffman E.G., Diner R., Villamil T. Elemental abundance anomalies in the late Cenomanian extinction interval: a search for the source(s) // Earth Planet. Sci. Lett., 1993, v. 117, p. 189-204. 
Owens J.D., Lyons T.W., Li X., Macleod K.G., Gordon G., Kuypers M.M.M., Anbar A., Kuhnt W., Severmann S. Iron isotope and trace metal records of iron cycling in the proto-North Atlantic during the Cenomanian-Turonian oceanic anoxic event (OAE-2) // Paleoceanography, 2012, v. 27, PA3223.

Owens J.D., Gill B.C., Jenkyns H.C., Bates S.M., Severmann S., Kuypers M.M.M., Woodfine R.G., Lyons T.W. Sulfur isotopes track the global extent and dynamics of euxinia during Cretaceous Oceanic Anoxic Event // Proceedings of the National Academy of Sciences of the United States of America, 2013, v. 110, № 46, p. $18407-18412$.

Owens J.D., Reinhard C.T., Rohrssen M., Loveb G.D., Lyons T.W. Empirical links between trace metal cycling and marine microbial ecology during a large perturbation to Earth's carbon cycle // Earth Planet. Sci. Lett., 2016, v. 449, p. 407-417.

Pearce M.A., Jarvis I., Tocher B.A. The Cenomanian-Turonian boundary event, OAE2 and palaeoenvironmental change in epicontinental seas: New insights from the dinocyst and geochemical records // Palaeogeogr. Palaeoclimatol. Palaeoecol., 2009, v. 280, p. 207-234.

Pogge von Strandmann P.A.P., Jenkyns H.C., Woodfine R.G. Lithium isotope evidence for enhanced weathering during Oceanic Anoxic Event $2 / /$ Nat. Geosci., 2013, v. 6, p. 668 - 672.

Portnyagin M., Savelyev D., Hoernle K., Hauff F., Garbe-Schönberg D. Mid-Cretaceous Hawaiian tholeiites preserved in Kamchatka // Geology, 2008, v. 36, p. 903-906.

Poulsen C.J., Barron E.J., Arthur M.A., Peterson W.H. Response of the mid-Cretaceous global oceanic circulation to tectonic and $\mathrm{CO}_{2}$ forcings // Paleoceanography, 2001, v. 16, № 6, p. 576-592.

Poulton S.W., Henkel S., März C., Urquhart H., Flögel S., Kasten S., Sinninghe Damsté J.S., Wagner T. A continental-weathering control on orbitally driven redox-nutrient cycling during Cretaceous Oceanic Anoxic Event 2 // Geology, 2015, v. 43, № 11, p. 963-966.

Premoli Silva I., Haggerty J., Rack F., Arnaud-Vanneau A., Bergersen D.D., Bogdanov Y., Bohrmann H.W., Buchardt B., Camoin G., Christie D.M., Dieu J.J., Enos P., Erba E., Fenner J.M., Gee J.S., Head M.J., Ito H., Hobbs P.R.N., Jansa L.F., Ladd J.W., Larson R.L., Hakanishi M., Ogg J.G., Opdyke B.M., Pearson P.N., Quinn T.M., Watkins D.K., Wilson P.A. Site 872 // Proceedings of the Ocean Drilling Program, Initial reports, v. 144, College Station, Texas, 1993, p. 105-144.

Price G.D. New constraints upon isotope variation during the early Cretaceous (Barremian-Cenomanian) from the Pacific Ocean // Geol. Mag., 2003, v. 140, № 5, p. 513-522.

Pucéat E. A new breath of life for anoxia // Geology, 2008, v. 36, p. 831-832.

Robinson S.A., Murphy D.P., Vance D., Thomas D.J. Formation of «Southern Component Water» in the Late Cretaceous: Evidence from Nd-isotope // Geology, 2010, v. 38, № 10, p. 871-874.

Sageman B.B., Meyers S.R., Arthur M.A. Orbital time scale and new C-isotope record for CenomanianTuronian boundary stratotype // Geology, 2006, v. 34, № 2, p. 125-128.

Sageman B.B., Rich J., Arthur M.A., Birchfield G.E., Dean W.E. Evidence for Milankovitch periodicities in Cenomanian-Turonian lithologic and geochemical cycles, Western Interior U.S. // J. Sediment. Res., 1997, v. 67, p. 286-301.

Savelyev D.P., Savelyeva O.L., Palechek T.N., Pokrovsky B.G. Carbon isotope curve and iridium anomaly in the Albian-Cenomanian paleoceanic deposits of the Eastern Kamchatka // Geophys. Res. Abstracts. V. 14. EGU2012-1940, EGU General Assembly 2012, p. 1940.

Savelyeva O., Palechek T., Savelyev D. First evidence of the Oceanic Anoxic Events in Cenomanian paleoceanic deposits of the Eastern Kamchatka // Geophys. Res. Abstracts. V. 12. EGU2010-3782, EGU General Assembly 2010, p. 3782.

Savelyeva O., Palesskiy S., Savelyev D. PGE in carbonaceous beds in the Cretaceous carbonate-siliceous section of the Kamchatsky Mys Peninsula (Russia) // Goldschmidt Abstracts, 2015, p. 2779.

Schlanger S.O., Jenkyns H.C. Cretaceous oceanic anoxic events: Causes and consequences // Geologie en Mijnbouw, 1976, v. 55, p. 179-184.

Schlanger S.O., Arthur M.A., Jenkyns H.C., Scholle P.A. The Cenomanian-Turonian oceanic anoxic event, I. Stratigraphy and distribution of organic carbon-rich beds and the marine $\delta^{13} \mathrm{C}$ excursion // Marine petroleum source rocks // Geol. Soc. Special Publ., 1987, № 26, p. 371-399.

Scopelliti G., Bellanca A., Coccioni R., Luciani V., Neri R., Baudin F., Chiari M., Marcucci M. Highresolution geochemical and biotic records of the Tethyan 'Bonarelli Level' (OAE2, latest Cenomanian) from the Calabianca-Guidaloca composite section, northwestern Sicily, Italy // Palaeogeogr. Palaeoclimatol. Palaeoecol., 2004, v. 208, p. $293-317$.

Scotese C.R. A continental drift flipbook // J. Geol., 2004, v. 112, p. 729-741.

Sinninghe Damsté J.S., Köster J. A euxinic southern North Atlantic Ocean during the Cenomanian/ Turonian oceanic anoxic event // Earth Planet. Sci. Lett., 1998, v. 158, p. 165-173. 
Sinninghe Damsté J.S., Kuypers M.M.M., Pancost R.D., Schouten S. The carbon isotopic response of algae, (cyano)bacteria, archaea and higher plants to the late Cenomanian perturbation of the global carbon cycle: Insights from biomarkers in black shales from the Cape Verde Basin (DSDP Site 367) // Org. Geochem. 2008, v. 39 , p. $1703-1718$.

Sinninghe Damsté J.S., van Bentum E.C., Reichart G.-J., Pross J., Schouten S. A $\mathrm{CO}_{2}$ decreasedriven cooling and increased latitudinal temperature gradient during the mid-Cretaceous Oceanic Anoxic Event 2 // Earth Planet. Sci. Lett., 2010, v. 293, p. 97-103.

Sinton C.W., Duncan R.A. Potential links between ocean plateau volcanism and global ocean anoxia at the Cenomanian-Turonian boundary // Econ. Geol., 1997, v. 92, p. 836-842.

Sliter W.V., Premoli Silva I. Age and origin of Cretaceous planktonic foraminifers from limestone of the Franciscan complex near Laytonville, California // Paleoceanography, 1990, v. 5, p. 639—667.

Snow L.J., Duncan R.A., Bralower T.J. Trace element abundances in the Rock Canyon Anticline, Pueblo, Colorado, marine sedimentary section and their relationship to Caribbean plateau construction and ocean anoxic event 2 // Paleoceanography, 2005, v. 20, PA3005.

Storey M., Mahoney J.J., Saunders A.D., Duncan R.A., Kelley S.P., Coffin M.F. Timing of hot spotrelated volcanism and the breakup of Madagascar and India // Science, 1995, v. 267, № 5199, p. 852 — 855 .

Takashima R., Kawabe F., Nishi H., Moriya K., Wani R., Ando H. Geology and stratigraphy of forearc basin sediments in Hokkaido, Japan: Cretaceous environmental events on the north-west Pacific margin // Cretaceous Res., 2004, v. 25, p. 365-390.

Takashima R., Nishi H., Huber B.T., Leckie R.M. Greenhouse world and the Mesozoic ocean // Oceanography, 2006, v. 19, № 4, p. 64-74.

Takashima R., Nishi H., Yamanaka T., Tomosugi T., Fernando A.G., Tanabe K., Moriya K., Kawabe F., Hayashi K. Prevailing oxic environments in the Pacific Ocean during the mid-Cretaceous Oceanic Anoxic Event 2 // Nat. Commun., 2011, v. 2, № 234, doi: 10.1038/ncomms1233.

Tarduno J.A., Brinkman D.B., Renne P.R., Cottrell R.D., Scher H., Castillo P. Evidence for extreme climatic warmth from Late Cretaceous Arctic vertebrates // Science, 1998, v. 282, p. 2241-2244.

Taylor S.R., McLennan S.M. The geochemical evolution of the continental crust // Rev. Geophys. 1995, v. 33, № 2, p. 241-265.

Tegner C., Storey M., Holm P.M., Thorarinsson S.B., Zhao X., Lo C.-H., Knudsen M.F. Magmatism and Eurekan deformation in the High Arctic Large Igneous Province: ${ }^{40} \mathrm{Ar}-{ }^{39} \mathrm{Ar}$ age of Kap Washington Group volcanics, North Greenland // Earth Planet. Sci. Lett., 2011, v. 303, p. 203-214.

Tejada M.L.G., Mahoney J.J., Duncan R.A., Hawkins M.P. Age and geochemistry of basement and alkalic rocks of Malaita and Santa Isabel, Solomon Islands, southern margin of Ontong Java Plateau // J. Petrol., 1996, v. 37, p. 361-394.

Thurow J., Brumsack H.-J., Rullkötter J., Littke R., Meyers P. The Cenomanian/Turonian boundary event in the Indian Ocean - A key to understand the global picture // Synthesis of results from scientific drilling in the Indian Ocean. Geophysical Monograph Series, American Geophysical Union, Washington, DC, 1992, v. 70 , p. $253-273$.

Torsvik T.H., Tucker R.D., Ashwal L.D., Eide E.A., Rakotosolofo N.A., de Wit M.J. Late Cretaceous magmatism in Madagascar: palaeomagnetic evidence for a stationary Marion hotspot // Earth Planet. Sci. Lett., 1998 , v. 164, p. $221-232$.

Trabucho-Alexandre J., Tuenter E., Henstra G.A., van der Zwan K.J., van de Wal R.S.W., Dijkstra H.A., de Boer P.L. The mid-Cretaceous North Atlantic nutrient trap: black shales and OAEs // Paleoceanography, 2010, v. 25, PA4201.

Tribovillard N., Algeo T.J., Lyons T., Riboulleau A. Trace metals as paleoredox and paleoproductivity proxies: An update // Chem. Geol., 2006, v. 232, p. 12-32.

Tsikos H., Jenkyns H.C., Walsworth-Bell B., Petrizzo M.R., Forster A., Kolonic S., Erba E., Premoli Silva I., Baas M., Wagner T., Sinninghe Damsté J.S. Carbon-isotope stratigraphy recorded by the Cenomanian-Turonian Oceanic Anoxic event; correlation and implications based on three key localities // J. Geol. Soc., 2004, v. 161, p. 711-719.

Turgeon S.C., Brumsack H.-J. Anoxic vs dysoxic events reflected in sediment geochemistry during the Cenomanian-Turonian boundary event (Cretaceous) in the Umbria-Marche Basin of central Italy // Chem. Geol., 2006, v. 234, p. 321-339.

Turgeon S.C., Creaser R.A. Cretaceous oceanic anoxic event 2 triggered by a massive magmatic episode // Nature, 2008, v. 454, p. 323-326.

Tyson R.V., Pearson T.H. Modern and ancient continental shelf anoxia: an overview // Modern and ancient continental shelf anoxia // Geol. Soc. Spec. Publ., 1991, № 58, p. 1-24. 
Van Cappellen P., Ingall E.D. Benthic phosphorus regeneration, net primary production, and ocean anoxia: A model of the coupled marine biogeochemical cycles of carbon and phosphorus // Paleoceanography, 1994, v. 9, p. 677-692.

Wan X., Wignall P.B., Zhao W. The Cenomanian-Turonian extinction and oceanic anoxic event: evidence from southern Tibet // Palaeogeogr. Palaeoclimatol. Palaeoecol., 2003, v. 199, p. 283-298.

Wang X., Reinhard C.T., Planavsky N.J., Owens J.D., Lyons T.W., Johnson T.M. Sedimentary chromium isotopic compositions across the Cretaceous OAE2 at Demerara Rise Site 1258 // Chem. Geol., 2016, v. 429, p. $85-92$.

Westermann S., Caron M., Fiet N., Fleitmann D., Matera V., Adatte T., Föllmi K.B. Evidence for oxic conditions during oceanic anoxic event 2 in the northern Tethyan pelagic realm // Cretaceous Res., 2010, v. 31, p. $500-514$.

Wignall P.B. Large igneous provinces and mass extinctions // Earth Sci. Rev., 2001, v. 53, p. 1-33.

Zheng X.-Y., Jenkyns H.C., Gale A.S., Ward D.J., Henderson G.M. Changing ocean circulation and hydrothermal inputs during Ocean Anoxic Event 2 (Cenomanian-Turonian): Evidence from Nd-isotopes in the European shelf sea // Earth Planet. Sci. Lett., 2013, v. 375, p. 338-348. 